الإرث التاريخي والمرثد السياحي ... تحديات وتكامل

" برنامج الإرشاد السياحي بجامعة الثارقة نموذجاتيا"

د. عمادالدين أحمد أبوالعنين

أستاذ مساعد، كلية الآداب وإلعلوم الإنسانية، جامعة الثارقة الثمانين

eabuelenain@sharjah.ac.ae

د. دل علي حسن خميس

أستاذ مساعد، كلية الآداب وإلعلوم الإنسانية، جامعة الثارقة

\title{
ali.khamis@sharjah.ac.ae
}

ملخص البحث

من الصعوبة بمكان انكار العلاقة الوثيقة بين التاريخ والإرشاد السياحي فهنالك رابط بينهما ما

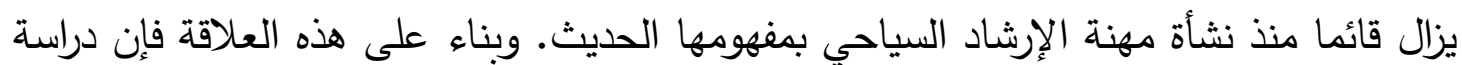

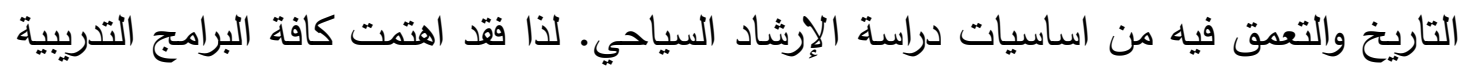

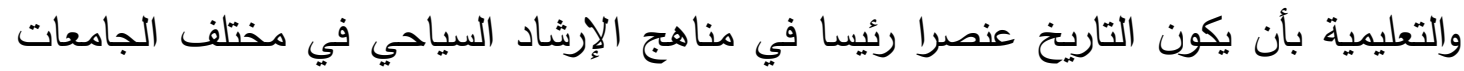

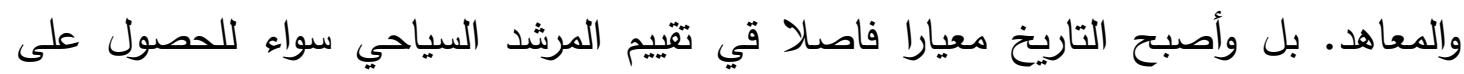
ترخيص مزاولة المهنة او لتجديد ذلك الترخيص كلما لزم الأمر وطبقا للوائح المعمول بها في في كل فلئل دولة.

وبناء على ذلك تتناول الدراسة مناقشة هذه القضية من منظور جديد ومتطور ليواكب التغيرات

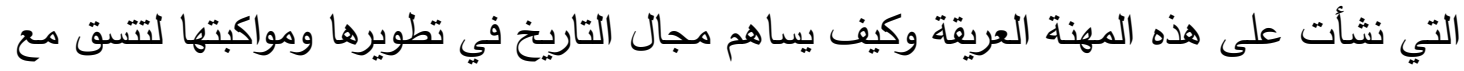
متغيرات العصر الحديث في هذا القطاع. تتناول الدراسة التحديات التي تواجه المرشد السياحي لهي في ظل تنوع انماط السياحة وتعددها، بل ومع تغير طبيعة السائح التي تشكل احتياجاته ورغباته

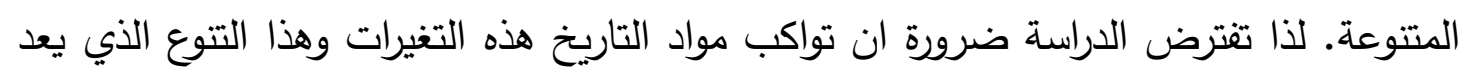

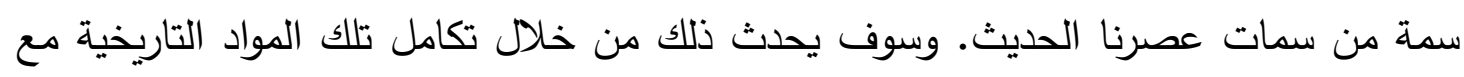
مواد السياحة والإرشاد السياحي من خلال دراسة واقعية لمتطلبات السوق السياحي ومن خلال منظور يركز على ما يحتاجه المرشد السياحي فعليا في عمله.

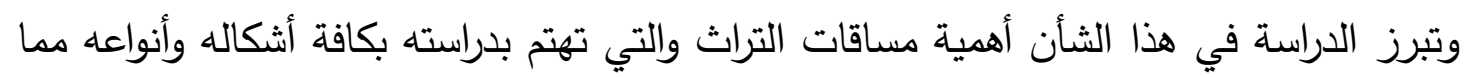

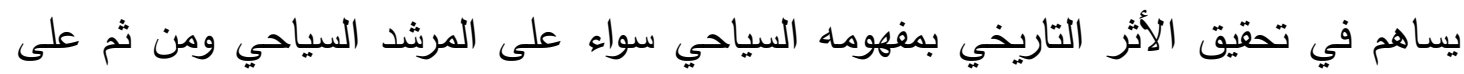

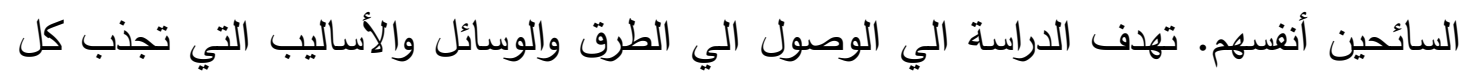

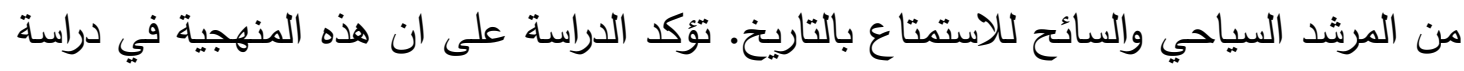
التاريخ لن تتنقص من الإرث التاريخي، ولكنها ستجعل للتاريخ رونقا وعبقا يدوم في ذهن الهن السائح 
طويلا وهذا هو معيار نجاح المرشد السياحي مما سيجعل من السائح عنصرا هاما في الترويج لثتافتنا العريقة. واتخذت الدراسة من تجربة المزاوجة بين التاريخ والسياحة في التجربة السياحية

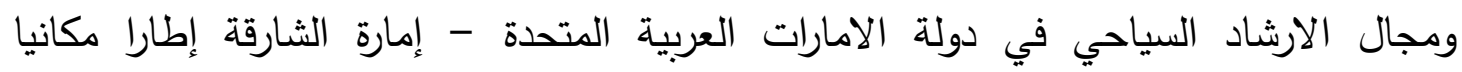

وموضوعيا.

الكلمات المفتاحية: أنماط سياحية، إرشاد سياحي، تاريخ، تراث، تعليم، ثقافة

المقدمة

يعد الإرشاد السياحي من المفاهيم التي أخذت تتعمق في صناعة السياحة، وذلك بسبب ازدياد الاهتمام من قبل الوجهات السياحية بهذه المهنة واعتبارها أساسية لتتوير السائح وتعميق معرفته بالمكان الذي يقصده، علاوة على إدراك مدي علاقته أحيانا بتكوين الصورة الذهنية لدي السائح عن الوجهة السياحية والسكان المحليين المتواجدين في هذه الوجهة. (الطائي، .... ؟: ص ع^).

ويتضمن التعريف العام للمرشد السياحي تحديد فئة المرشدين السياحيين بأنهم " أولئك الأشخاص الذين يقومون بإدارة الرحلة السياحية ( سواء أكانت متضمنة لمجموعة من السياح أو لشخص واحد فقط) ويملكون قدرا كافياً من المعرفة والمعلومات عن مكان معين، والتي تكون بدورها ضرورية لإعطاء السياح الصورة

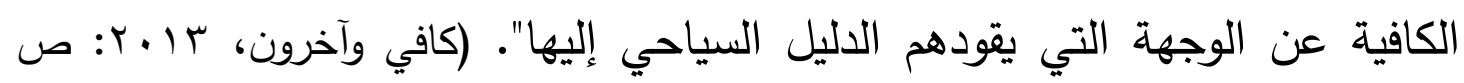

وفعلاً لم يظهر مفهوم الدليل السياحي بمفهومه المبسط إلا بعد قيام الثورة الصناعية، ومع ظهور

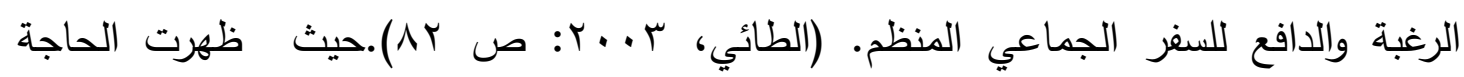

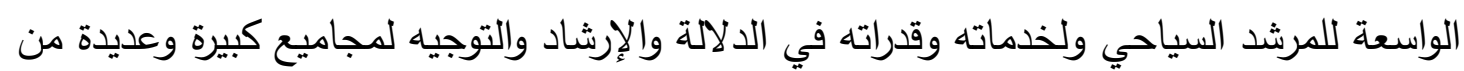

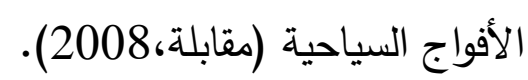

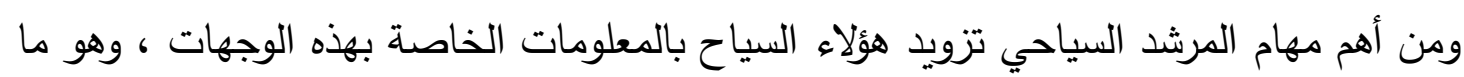

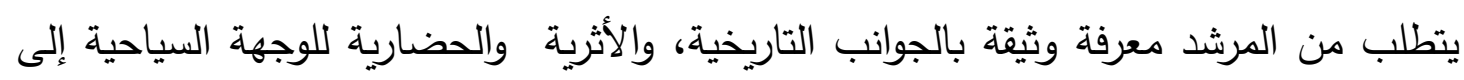

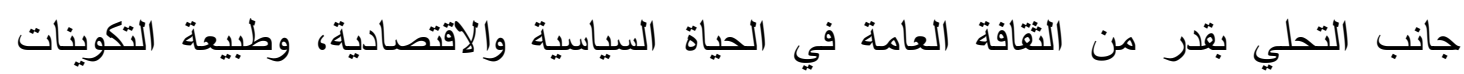
الاجتماعية ، وهي أمور في مجملها تعد ضرورية لمواجهة تعطش السياح القادمين للمعرفة والاطلاع على خصائص الوجهة السياحية التي يزورونها. (Cruz, 2008). 
لقد كان الإنسان القديم الأكثر حاجة إلى وجود من يدله ويرشده في ترحاله، لأنه كان يتحرك في

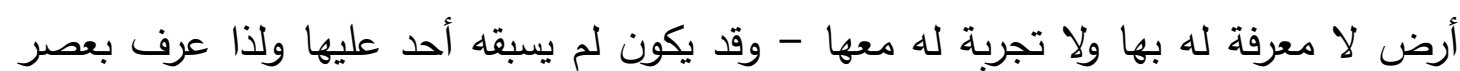

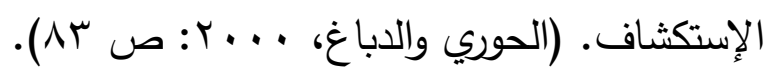

كانت مهمة الدليل في عصور ما قبل الإسلام ان يصاحب القوان القوافل التجارية آنذالك ويعرف باسم

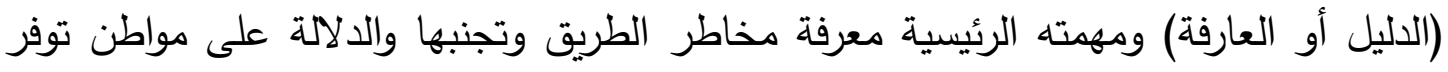
الماء والعشب والراحة، حيث كان للقافلة من يحميها من الفرسان والمقاتلين ويقف بوجه المعتدين

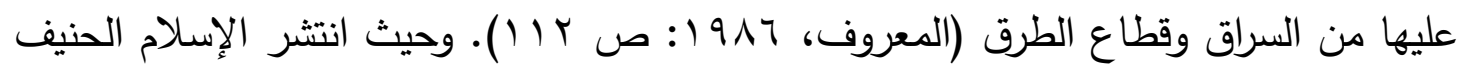

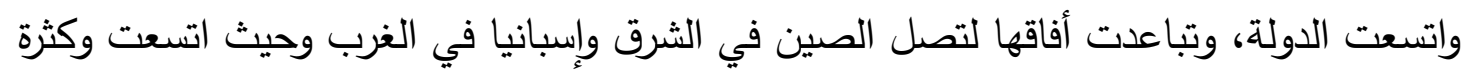

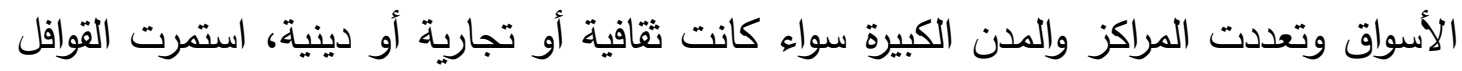
في الحركة بأفراد ومجاميع ذات أهداف عديدة (تجارية، ثقافية، دينية وطلباً للعلم والمعرفة، وحباً بالاستطلاع ومعرفة البلدان)، وتحركت كذلك الجيوش بهدف نشر الدات الدين الحنيف وإيصاله إلى إلى أبعد نقطة ممكنة، والحج إلى بيت الله الحرام - مكة المكرمة، وزيارة المدينة المنورة وقبر الرسول

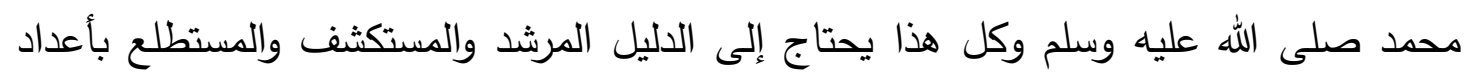

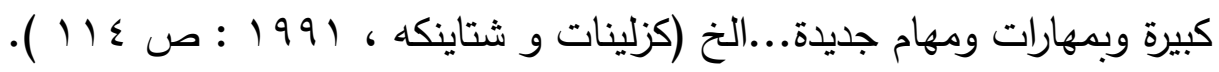

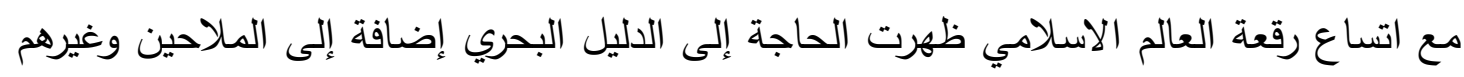
من العاملين في الملاحة وأفضل مثال على تعاظم الحاجة إليهم، "كتاب (المسالك والممالك)

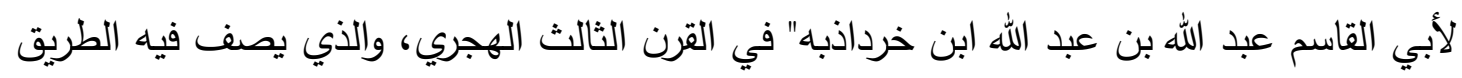

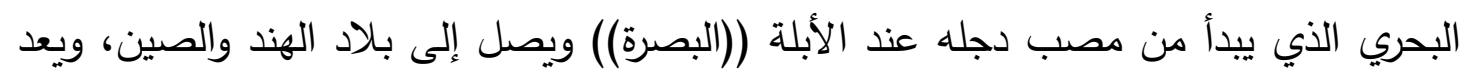

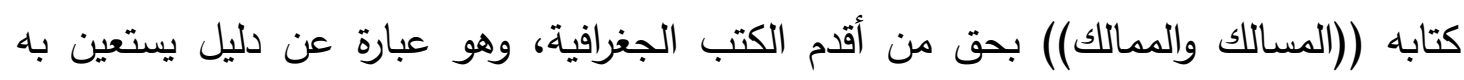

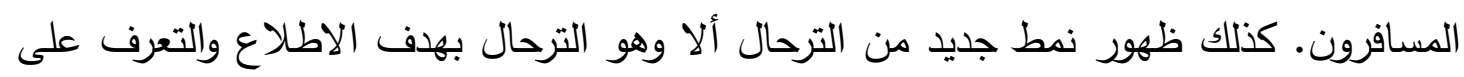
البلدان الجديدة والثعوب القريبة كل هذا بفضل اهتمام الخلفاء العباسيين بالتجارة تطوراً وازدهاراً،

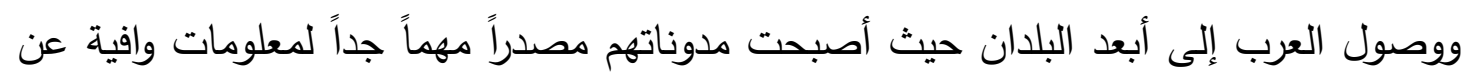

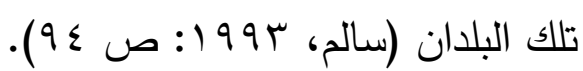
وظهر بعد ذلك منظمو الرحلات اللذين تمكنوا من تجميع كافة عناصر البرنامج السياحي من

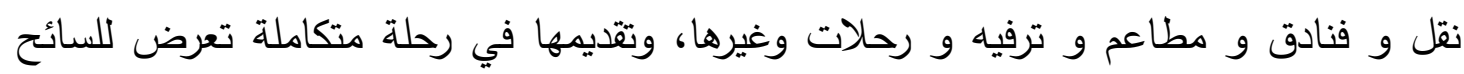

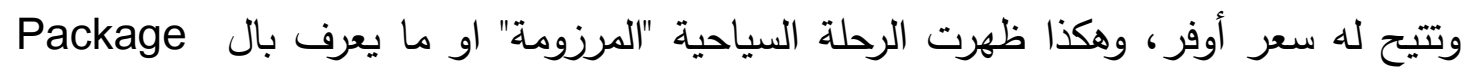

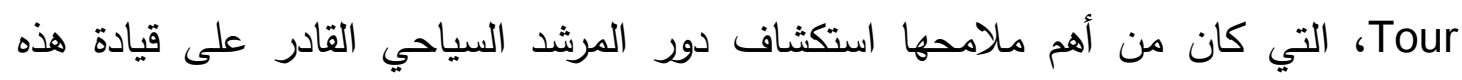

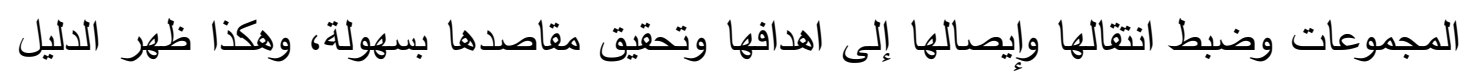

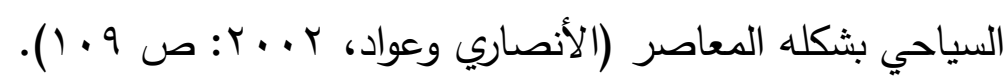


مما تقدم نجد أن الإرشاد ليس من نتاجات عصرنا هذا، ولا هو من إفرازات حضارة وثقافة ومدينة ومجتمعاتتا المعاصرة، بل العكس، فهو عمل ونشاط إنساني ظهرت الحاجة إليه وباتت بدايات أهميته يوم ظهرت حاجة الإنسان إلى الترحال - أي منذ ترك الإنسان القديم الكهوف والمغاور نحو الأراضي المتموجة والسهول. أي أنه حاجة تبلورت مع تدجين الإنسان للحيوانات الأليفة

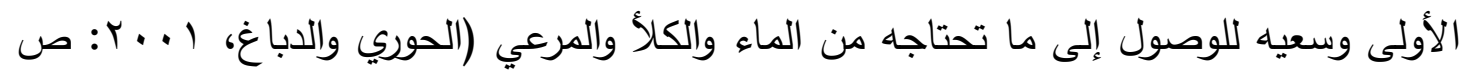

\section{أهمية الدراسة}

تعتبر الآثار التاريخية واحدا من اهم أدوات التعرف على ماضي الشعوب والحضارات، كما انها تعتبر المنبع الأساس الذي تستقى منه عناصر ومفردات الارث الحضاري لأمة او دولة، ولا تقوم سياحة ثقافية في عالم الاقتصاد الا على قاعدة من تراث مادي او ارث ثقافي غير مادي (مادي والمبروك، 9 . . :صع ) ، ومن خلال كل ذلك يصار لمعرفة تفاصيل التطور التاريخي الذي عاشه مجتمع ما في مختلف الجوانب الاجتماعية والسياسية والاقتصادية والعلمية، ولعل الآثار تقدم الدلائل الأكثر موضوعية ودقة على تاريخية اثر او شاهد حضاري في مجتمع إذا ما قيست بالتاريخ المدون الذي تشوبه الكثير من العوارض التي تعرض موضوعيته وحياديته لكثير من الثك والاستفهام، ولذلك يتزايد الاهتمام بها على المستوى العالمي (فضل الله، 9 ... :ص

هذا وقد اصبحت المكونات التراثية في اي مجتمع مقوما أساسيا لأية نهضة سياحية وموردا

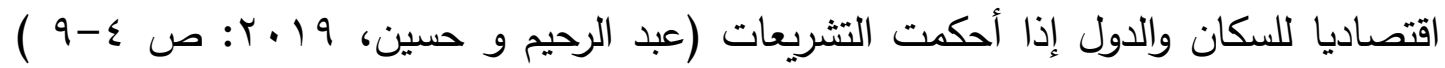
وأحسنت إدارة هذه الموارد ووضعت الخطط للاستفادة الحقيقية بما يعود على الاقتصاد بالريع

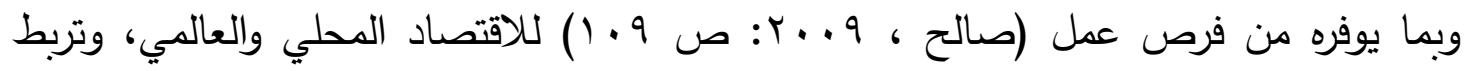
الديانات بين واجبات الدين ومنافع الدنيا وتوظيف التجمعات الدينية لأغراض اقتصادية، وليس أدل على ذلك مما أثار لله القرآن الكريم من ربط بين السياحة الدينية والجوانب الاقتصادية في أداء فريضة الحج بقوله سبحانه وتعالى " ليشهدوا منافع لهم ويذكروا اسم الله في أيام معلومات" (سورة الحج: آية ^^) ، بل ما يتضمنه موسم الحج من جوانب تاريخية وشواهد تراثيه عبر رحلة

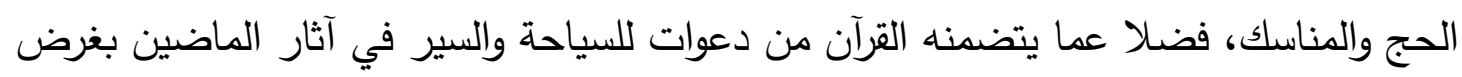
الاعتبار والتأمل في سنن الكون والوجود، يقول سبحانه وتعالى": قل سيروا في الأرض فانظروا كيف بدأ الخلق" (سورة العنكبوت: آية 9 (1) ويقول سبحانه وتعالى "قل سيروا في الأرض فانظروا كيف كان عاقبة الذين من قبل" (سورة الروم: آية rع). 
ومن هنا فإن أهمية الدراسة تأتي من أهية توظيف التاريخ بشكل علمي وموضوعي في خدمة

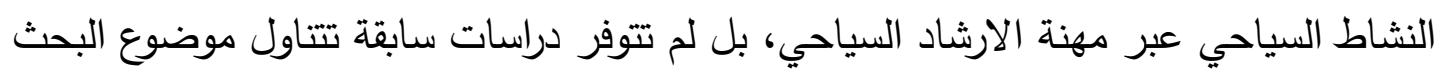
بشكل مباشر فيما يخص دولة الامارات او إمارة الثارقة. منهجية الدراسة مبانر فئا

تهدف هذه الدراسة إلى التعرف على الأثر المتبادل بين الإششاد السياحي والتاريخ والتحديات

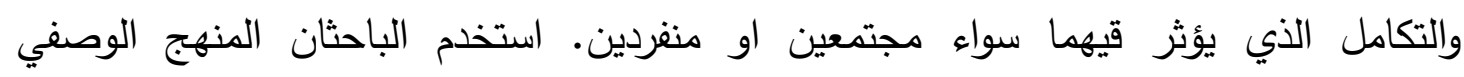
والتحليلي لكي يتم تحقيق هدف البحث وذلك عن طريق وصف ماء ماندين هو قائم واستخلاص الحقائق.

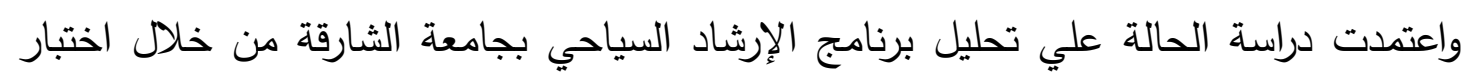

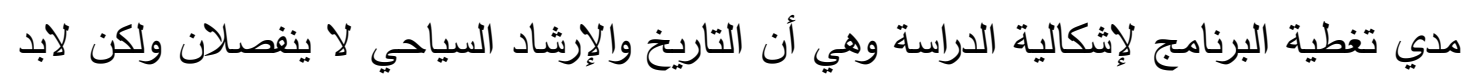

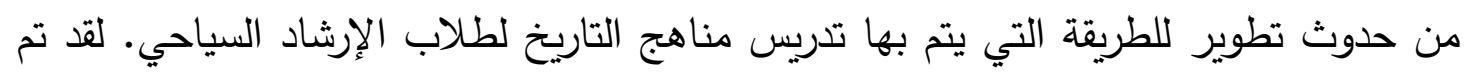

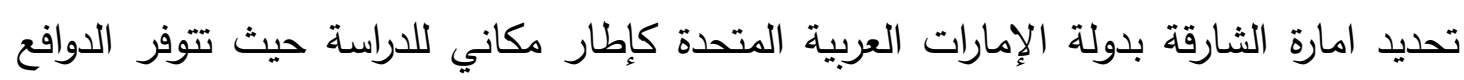
والإحتياجات لتطوير صناعة السياحة في الإمارة بشكل عام ومهنة الإشاد السياحي بين مواطني

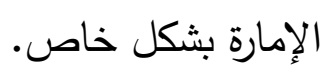

\section{أهمية الإرشاد السياحي في القطاع السياحي}

ويربط البعض بين انتشار الطلب على المرشدين السياحيين وبين تطور الحركة السياحية وتوزيع الطلب السياحي العالمي، فالنمو في الطلب السياحي يعكس نمواً في الطلب على المرشدين السياحيين، لكن بالمقابل نجد أن هنالك طلباً حاداً على المرشدين في الوجهات التي تكثر فيها العوائق والتحديات كالصين ولبعض الدول التي تعاني من مشاكل سياسية أو اجتماعية أو أمنية، علاوة على أن الوجهات الغريبة وغير المألوفة عادة ما تتطلب تواجداء للمرشد برفقة السياح.

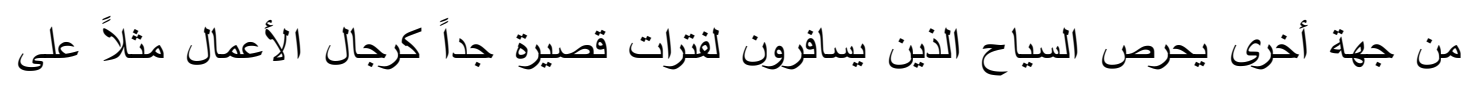

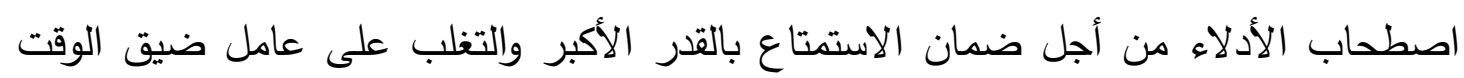

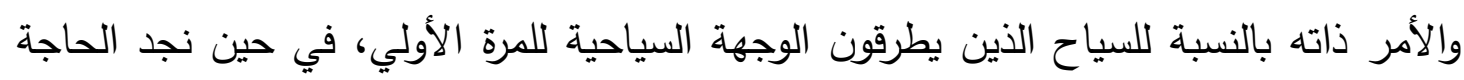

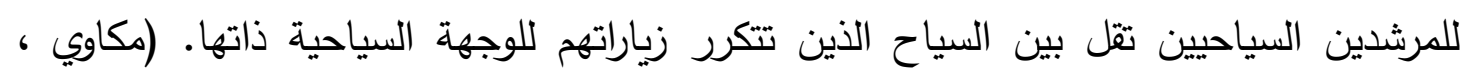

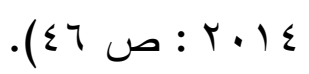

\section{أهمية مهنة الإششاد السياحي في إمارة الثارقة}

تتباهى الشارقة بمقوماتها السياحية المتميزة، والتي جعلت منها الوجهة الأولى للسياحة الترفيهادية التهية

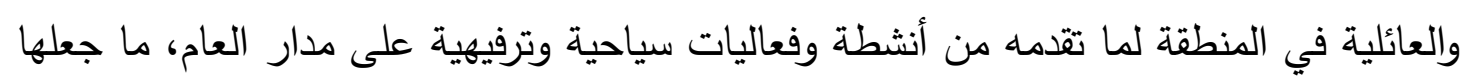




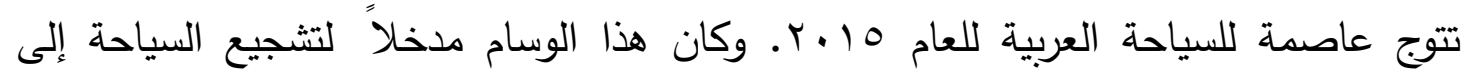

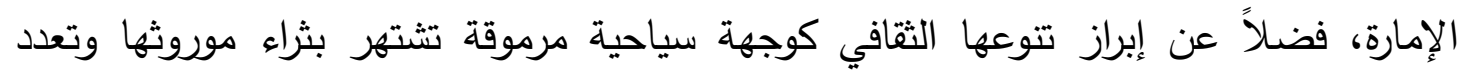

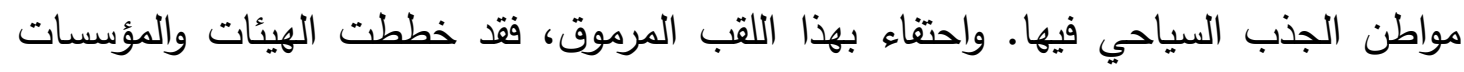
الحكومية، بما في ذلك هيئة الإنماء التجاري والسياحي بالشارقة، وعلى مدار العام، لإقامة العامة العديد

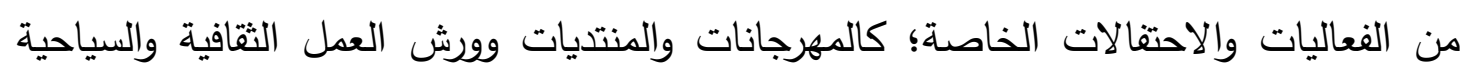
والفعاليات الترفيهية العائلية. وفي عام ؛ ا.بr، توجت الإمارة عاصمة للثقافة الإسلامية تقديراً

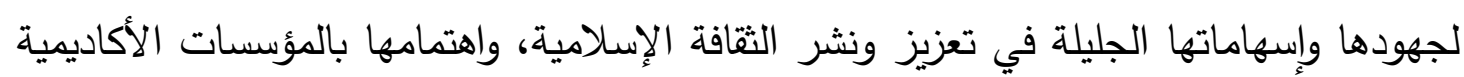
والثقافية والفكرية والعلمية التي ترجمت رؤية سموه في الدعوة إلى حوار الحضارات، والتسامح

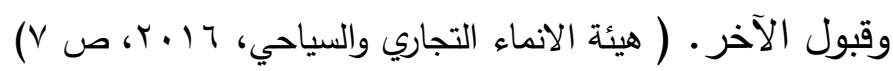

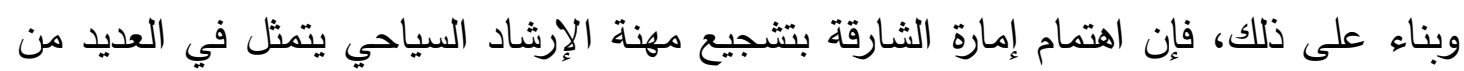

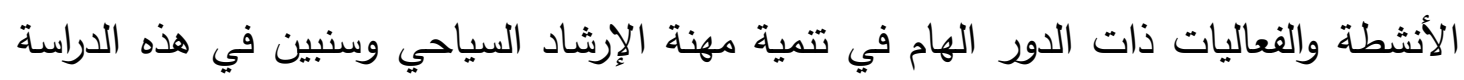

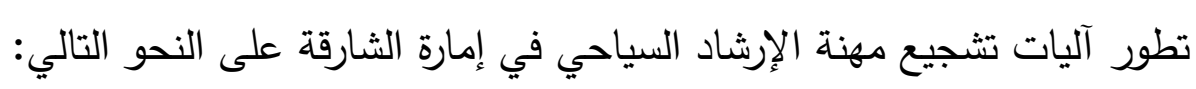

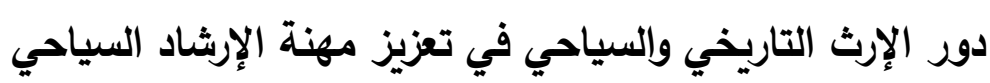

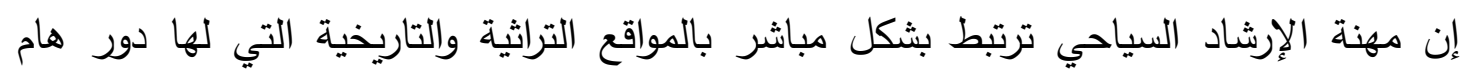

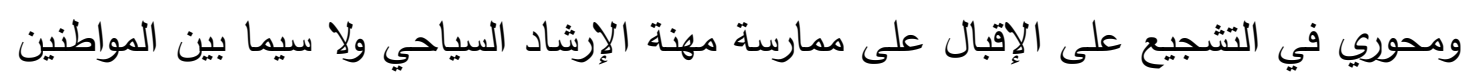

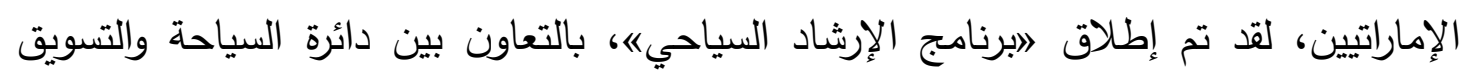

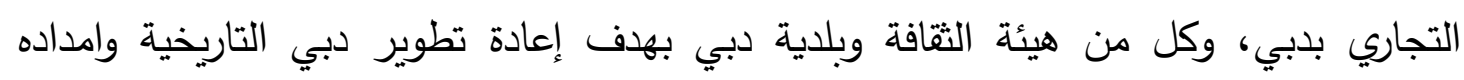

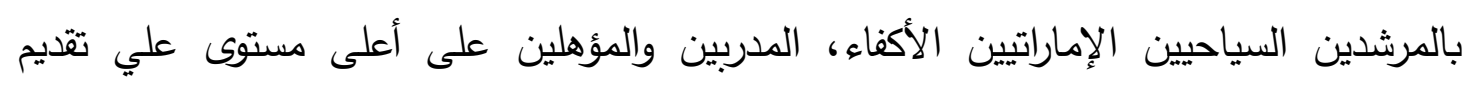

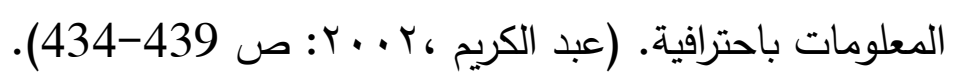

وسنبين في هذه الدراسة الدور المحوري لمواقع التراث في تعزيز التعليم في مجال الإرشاد

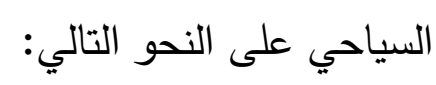

تطور دور الهيئات السياحية في تثجيع مهنة الإششاد السياحي إن للهيئات السياحية دور هام ومحوري في تثجيع مهنة الإششاد السياحي، ولا سيما في إطار المسؤولية عن تنظيم صناعة السياحة وإدارتها في الدولة، بشكل يضمن التنسيق التام والفعال

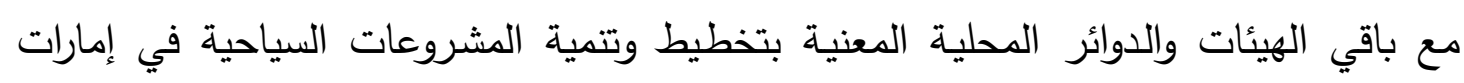

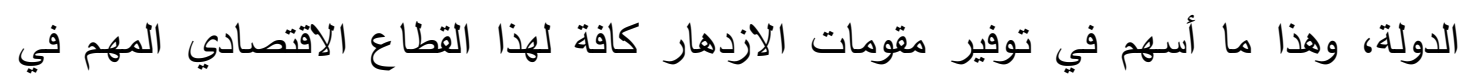

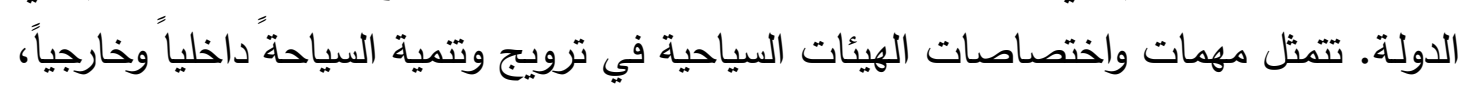

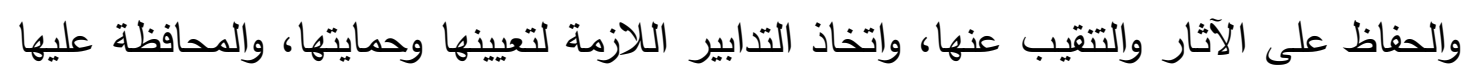


وتسجيلها وإحيائها وعرضها في الداخل والخارج، وتمثيل الدولة خارجياً, في كل ما يتعلق

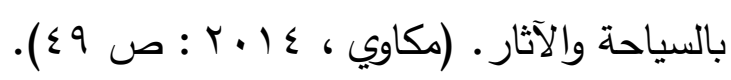

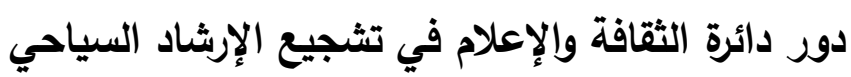

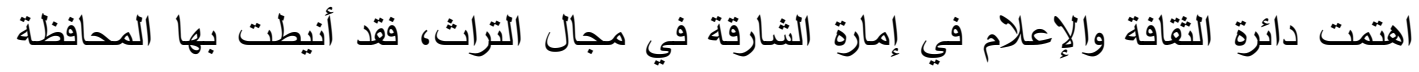

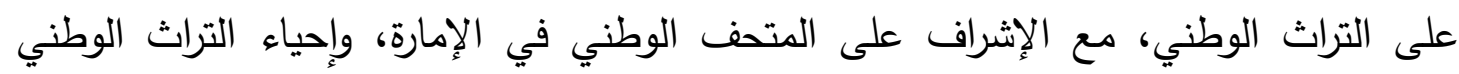

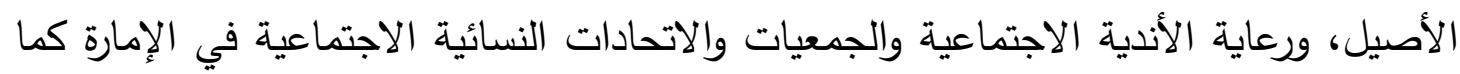

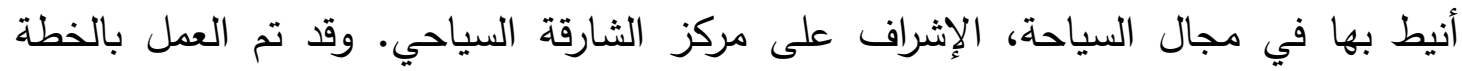

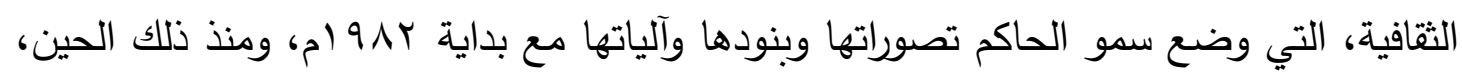

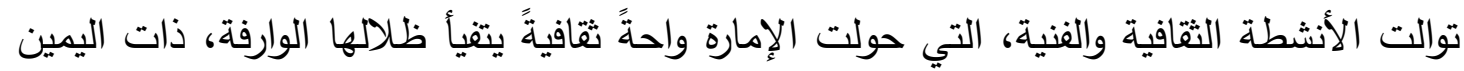

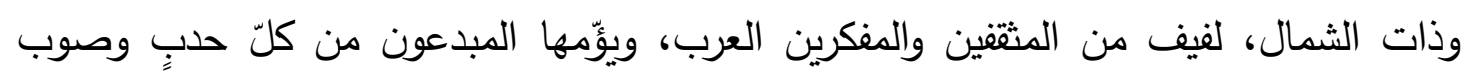

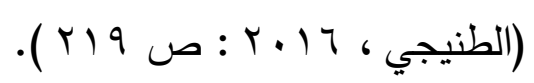

وبناء على ذلك، فإن دور دائرة الإعلام والثقافة في مجال تشجيع الارشاد السياحي يتمثل في

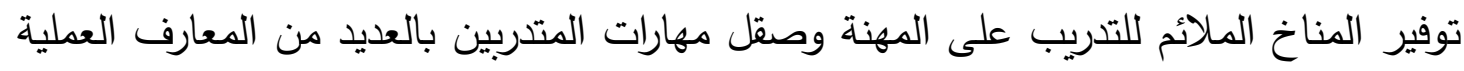

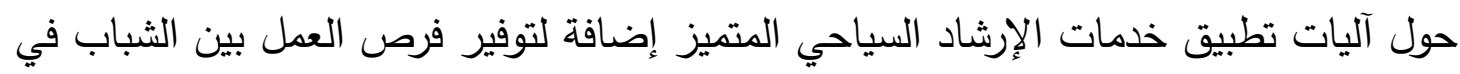

$$
\text { مجال الإششاد السياحي. }
$$

\section{دور الإطار القانوني في تثجيع مهنة الإرشاد السياحي.}

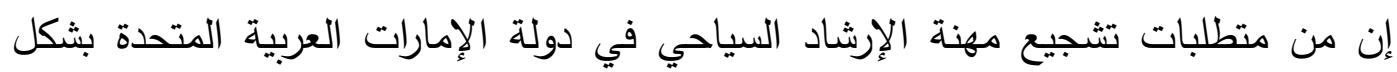

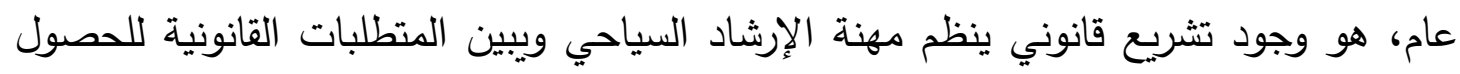

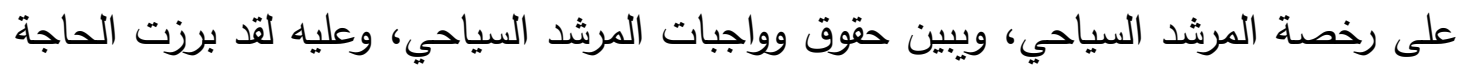
لوضع هذا القانون بعد ضبط عدد من لصوص الآثار الذين قاموا بسرقة بعض المضئ المواقع الأثرية

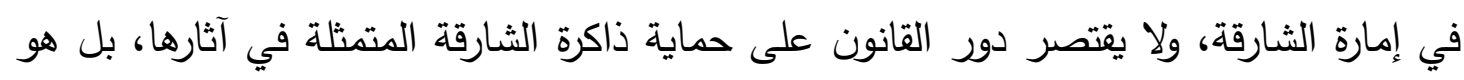

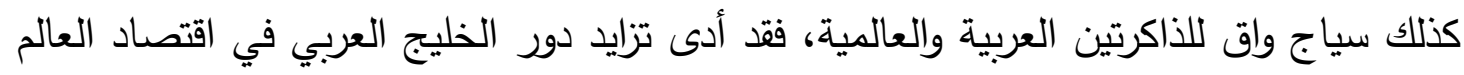

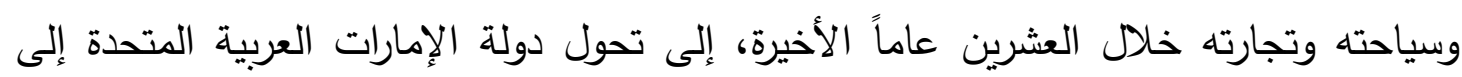

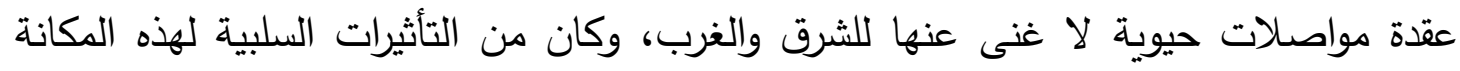

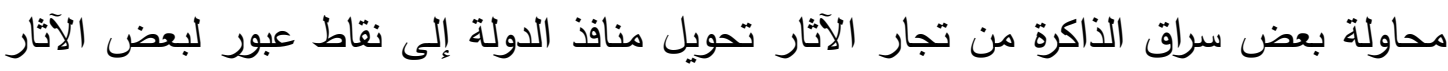

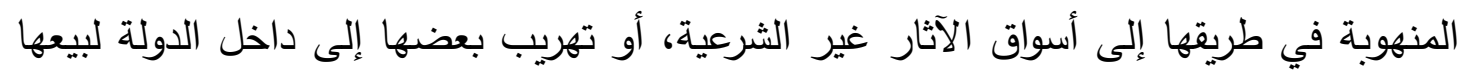

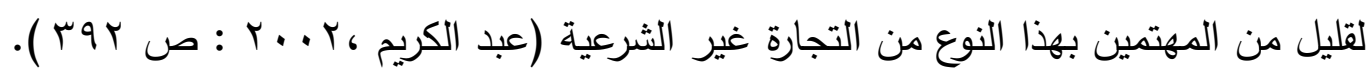
وتكمن أهمية الجانب القانوني في تشجع مهنة الإرشاد السياحي في أن القانون يساعد المرشدين

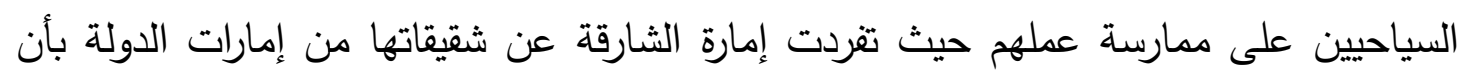


وضعت أول قانون لحماية الآثار والمحافظة عليها، والذي أصدره سمو حاكم الثارقة في آذار/

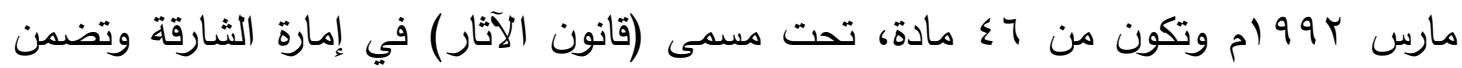

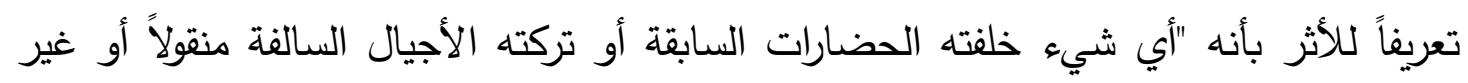

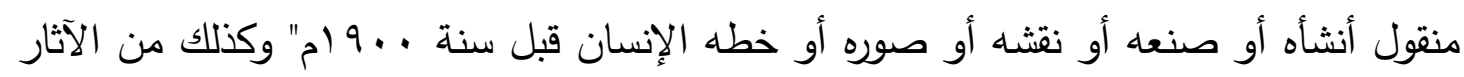

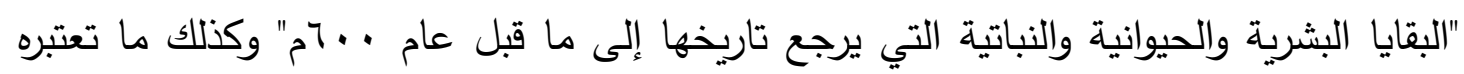

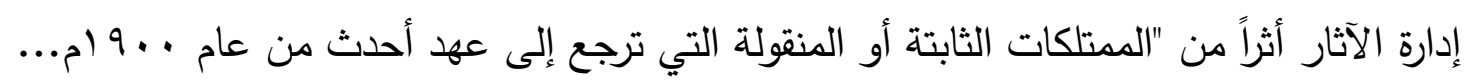

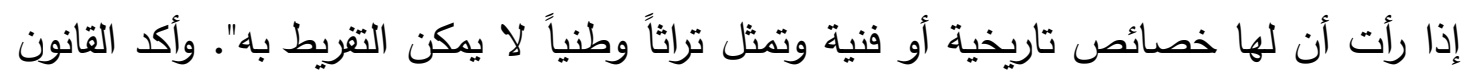

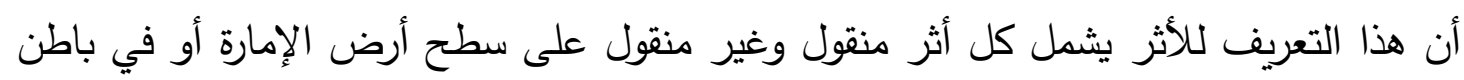

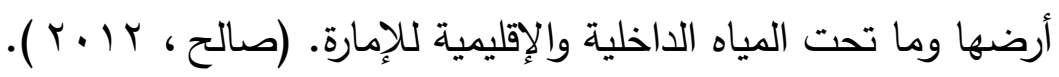

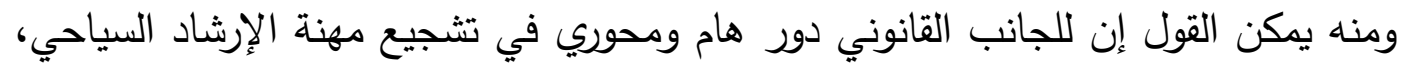
ولا سيما أنه يبين حقوق وواجبات المرشدين السياحيين، ويبين المتطلبات القانونية لممارسة مهنة

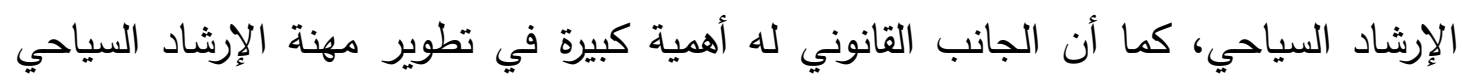
وتشجيعها من خلال وجود قالب قانوني خاص بمهنة الإرشاد السياحي على مستوى إمارة الثارقة

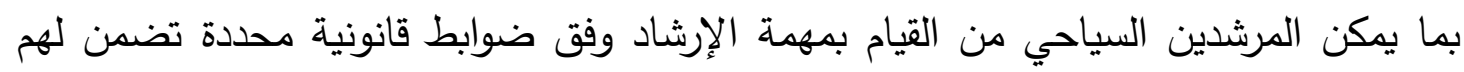
حقوقهم وترتب عليهم الالتزامات.

لقد تزايد الإقبال على مهنة الإرشاد السياحي في إمارة الثارقة نظراً للتظيم القانوني والإداري

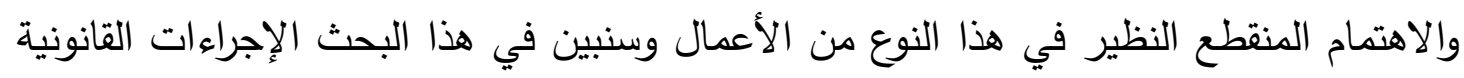

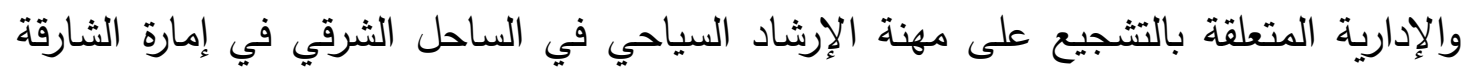

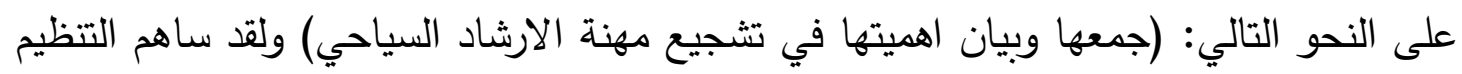

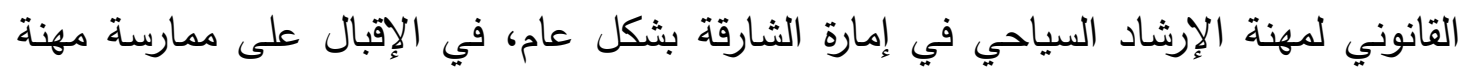

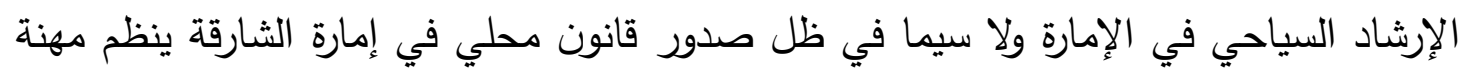

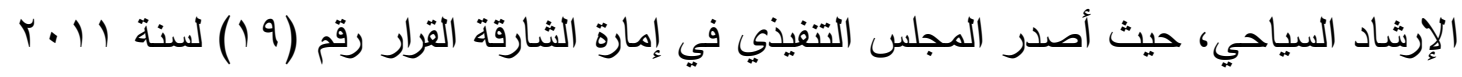
بشأن تتظيم مهنة الإرشاد السياحي في الإمارة حيث عرف القرار في مادته الأولى المرشد السياحي بأنه:" الشخص الطبيعي المرخص لله من قبل الهيئة الذي يقوم بإششاد السياح ومرافقتهم بمختلف المواقع السياحية والأثرية في الإمارة وتزويدهم بالمعلومات عنها" (حكومة الثارقة ، $\cdot(r+1)$ دور المراكز الثقافية إن للمراكز الثقافية أهية كبيرة ومحورية في تشجيع مهنة الإرشاد السياحي وتشجيعها، وخاصة فيما يتعلق بالإقبال على مهنة الإششاد السياحي من قبل المواطنين الإماراتيين، ومن أبرز الأدلة 
على ذلك أنه افتتح المركز الثقافي بتوجيهات من "سمو حاكم الثارقة سمو الثيخ الدكتور سلطان

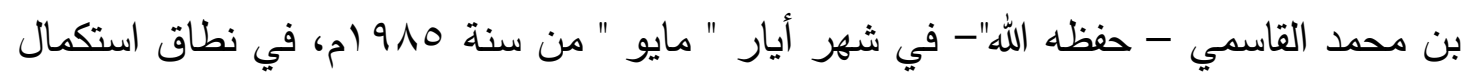

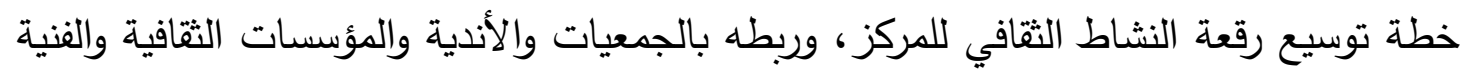

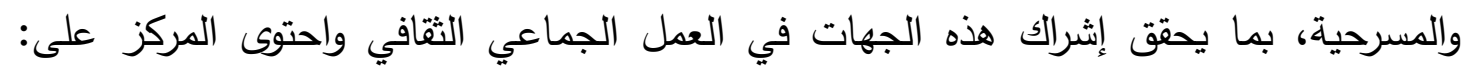

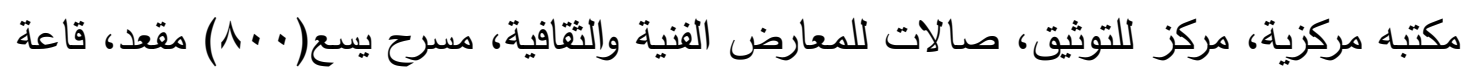
للمحاضرات، قاعات صغيرة للأنشطة التخصصية، مساحات وفضاءات خارجية مناسبة للأنشطة مركة

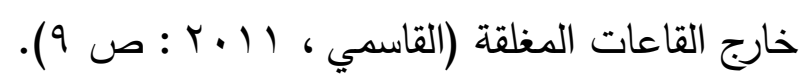
ومنه فإن افتتاح هذا المركز الثقافي كان له دور كبير في توفير فرص العمل في في مجال الإششاد السياحي، وتتمية المهارات الخاصة بمهنة الإشاد السياحي في إمارة الثارقة، ولاسيما

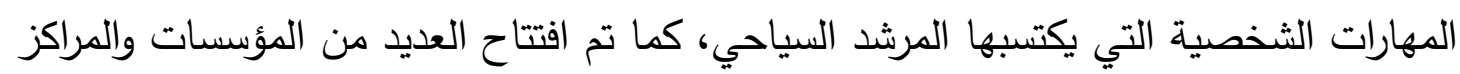
الثقافية والتعليمية، التي ساهدت في انتعاش الحرالك الثقافي في الإمارة، من بينها: افتتاح مكتبة

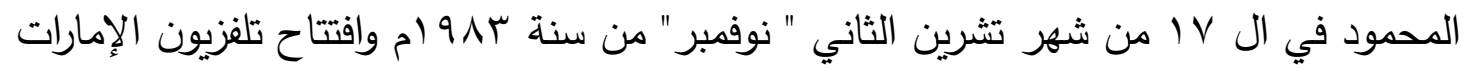

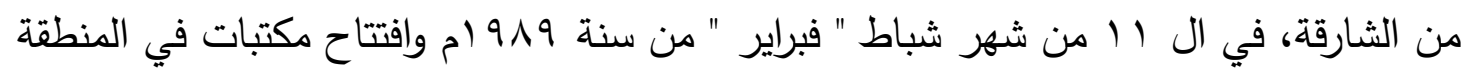
الشرقية: مكتبة كلباء، في ال م من شهر آذار "مارس" من سنة 919 (م، وكل هذه المؤسسات

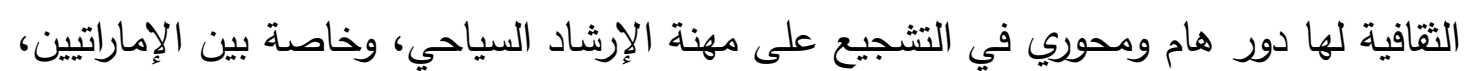

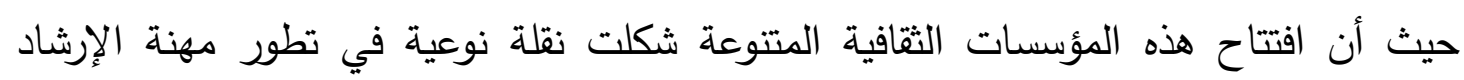

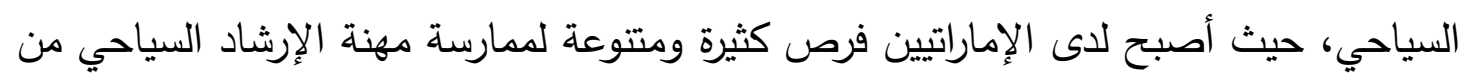
خلال التطبيق العملي للمهنة داخل هذه المؤسسات الثقافية التي تعتبر الميدان الحقيقي للممارسة

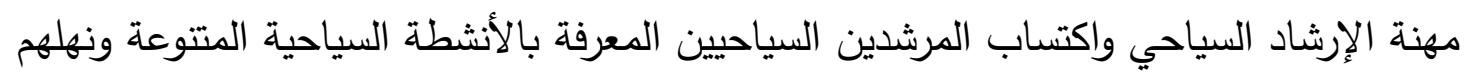

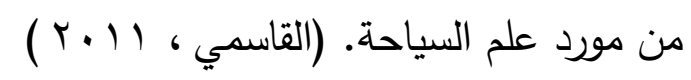


دور المتاحف في تعزيز مهنة الإرشاد السياحي: إن للمتاحف دور كبير وهام في تعزيز مهنة الإششاد السياحي في دولة الإمارات العربية المتحدة بشكل عام، وفي إمارة الشارقة على وجه الخصوص، وسنبين هنا أهم تلك المتاحف ودورها في تتمية وتثجيع وريادة مهنة الإرشاد السياحي على النحو التالي: فمن منطلق اهتمام إمارة الشارقة بمهنة الإششاد السياحي وتعزيز السياحة تم افتتاح القرية التراثية: حيث افتتحت القرية التي أقيمت بمناسبة المهرجان الثامن لثقافة الطفل في ال بr من شهر شباط " فبراير" من سنة بو99 (م، واشتملت أقسامها على ملامح من التراث، مثّلت الأنشطة المختلفة في الدولة في عهد ما قبل النفط، وأقيمت قرية تراثية أخرى في كلباء، ضمن أنشطة المهرجان (القاسمي ، (1) (1)) ، وكان لافتتاح هذه القرية دور وأثر كبير في تشجيع مهنة الإرشاد السياحي، حيث أنها تعتبر بمثابة التجربة العملية التطبيقية لمهنة الإشاد السياحي في الإمارة، ومن خلالها تمكن المرشدين السياحيين من التدريب على آليات ومهارات الإرشاد السياحي. افتتاح متحف الثارقة للآثار، في اله ا من شهر كانون الثاني "يناير" من سنة سو9 (م، والذي كان لله دور هام ومحوري في تشجيع مهنة الإرشاد السياحي، وخاصة من ناحية أن افتتاح هذا المتحف مكنت العديد من المرشدين السياحيين من تتمية مهاراتهم ومواهبهم في تطبيق مهنة الإرشاد السياحي على أرض الواقع. كذلك شكل افتتاح متحف الشارقة للفنون، في ال ب امن شهر نيسان "ابريل" من سنة 990 ام نقلة نوعية مهمة في تتمية السياحة في إمارة الشارقة، ووفر

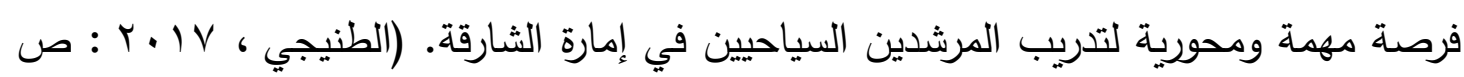

(TRY

وبعد ذلك بنحو عامين جاء افتتاح منطقة الفنون، في اليوم الأول من شهر تشرين الثاني " نوفمبر " من سنة 990 ام، كخطوة مهمة نحو تعزيز مهنة الإرشاد السياحي في إمارة الشارقة، حيث أنها مكنت المرشدين السياحيين من تجربة قدرتهم على ممارسة مهنة الإرشاد السياحي، وواكب ذلك في نفس العام افتتاح متحف التاريخ الطبيعي، في الم من شهر تشرين الثاني "نوفمبر" من سنة و99 ام، وهي مناسبة وفرت فرصة حقيقية ومهمة لتعزيز مهنة الإششاد السياحي وذلك من خلال تتمية مهارات المرشدين السياحيين وصقل مهاراتهم من خلال تعرفهم على العديد من الأمور والمعلومات الخاصة بالتاريخ الطبيعي، وهو ما يمكن اعتباره تخصصا وحقلا جديدا في اختصاص الإرشاد السياحي يكمن في الإششاد السياحي في مجال التاريخ

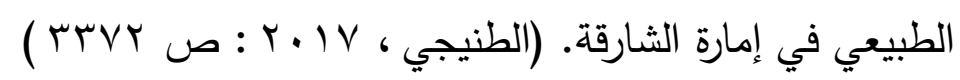
اما العام التالي فقد شهد افتتاح متحف الشارقة العلمي، في ال V من شهر نيسان "ابريل" من سنة 999 ام، وكان كذلك له دور هام في تعزيز مهنة الإششاد السياحي من حيث توفير المزيد 
من فرص العمل للمرشدين السياحيين وخاصة الإماراتيين منهم، فالاهتمام بالمتاحف في إمارة

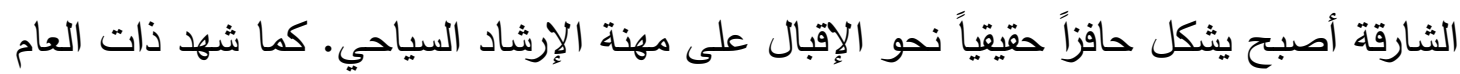

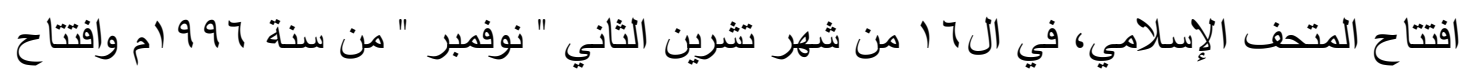
مراكز ثقافية: ضمن متحف الشارقة للفنون، وحصن الشارقة، ومتحف الشارقة للآثار كل هذه

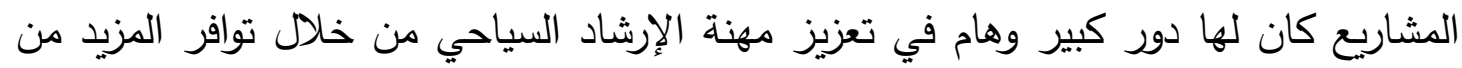

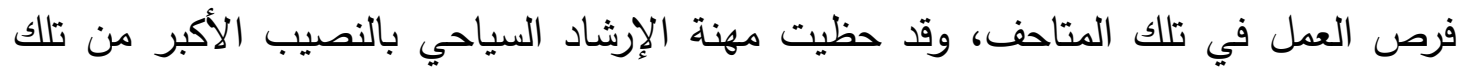

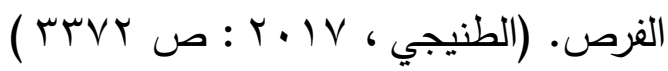
بينما بعد مرور r سنوات من ذلك التاريخ شهذ افتتاح مراكز الاستكشاف، في المیا من شهر

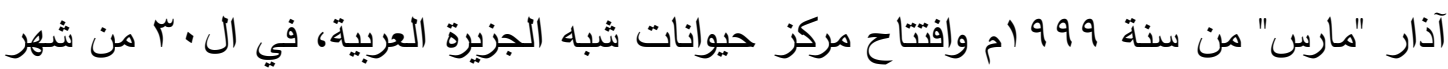

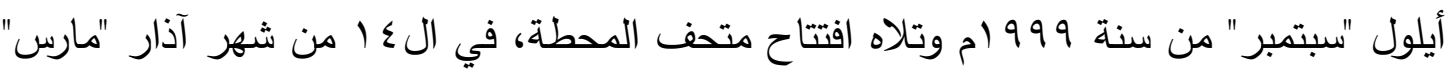

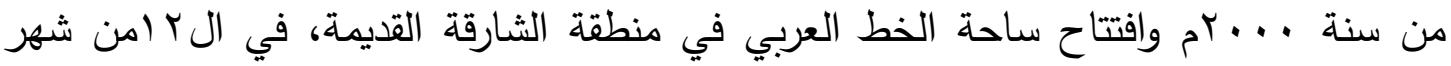
حزيران "يونيو" من سنة ץ. +. rم، وضمت: متحف الثارقة لفن الخط العربي والزخرفة، مركز الثارقة لفن الخط العربي والزخرفة، بيوت الخطاطين، بيت الزخرفة وضند وافتتاح متحف الثارقة

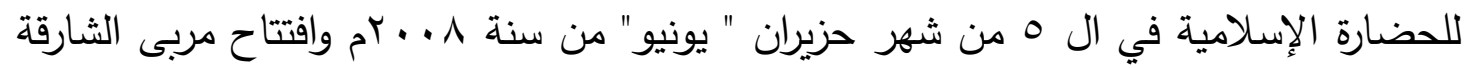

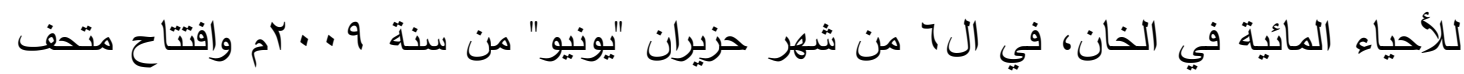

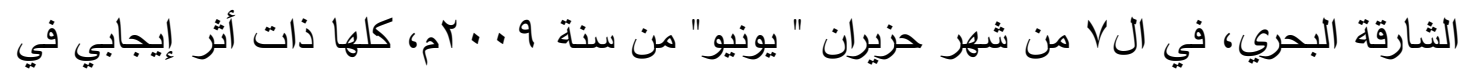

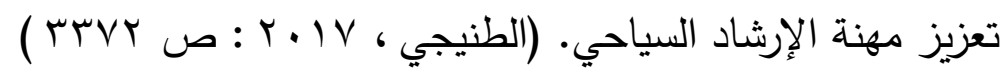

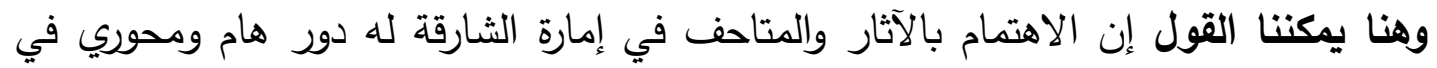

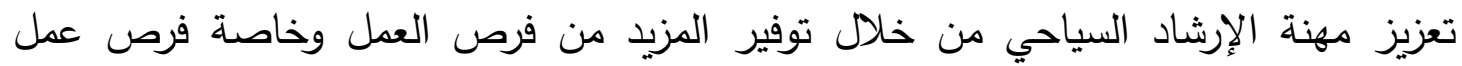

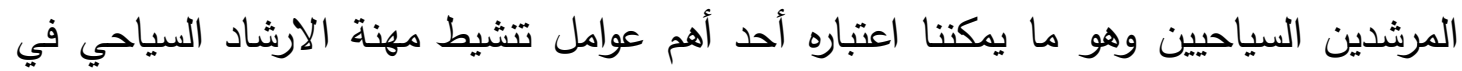

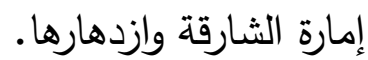

دور الهيئات السياحية في تعليم وتدريب المرثد السياحي

كما أن للإطار المؤسسي في مجال السياحة ودوره في تشجيع الإقبال على مهنة الإرشاد السياحي في إمارة الشارقة وجود العديد من المؤسسات التعليمية التي تعنى بتتشيط مهنة الإرشاد

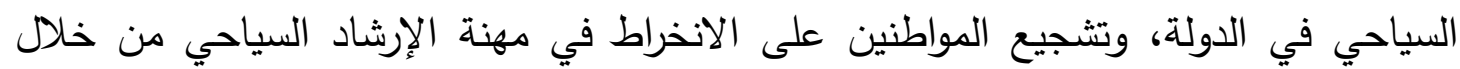

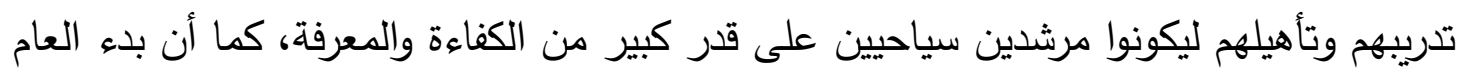

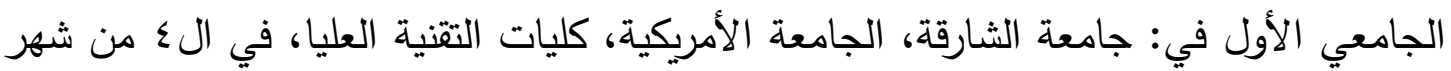

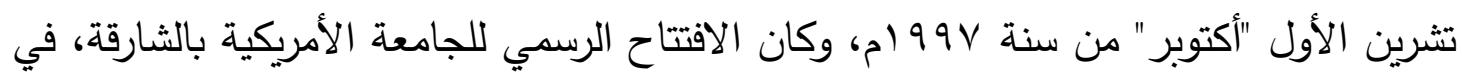




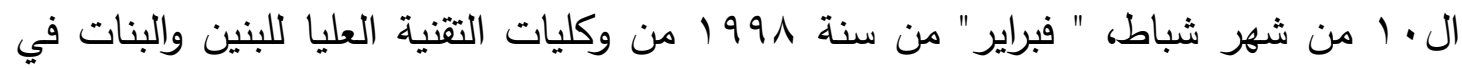

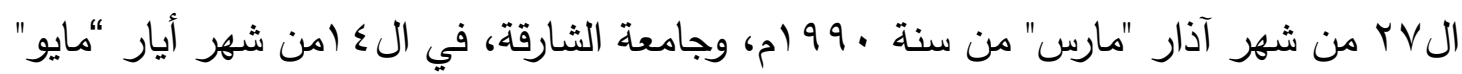

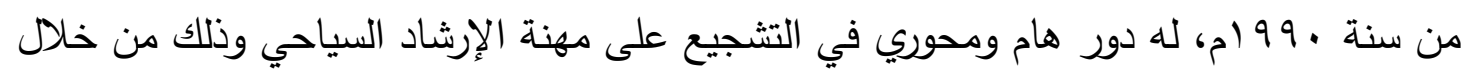

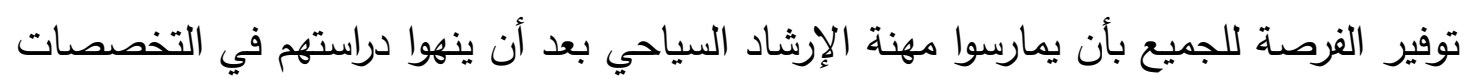

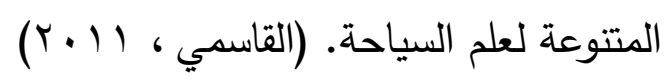
وسنبين هنا بعض الفعاليات الخاصة بتدريب المرشدين السياحيين في دولة الإمارات العربية

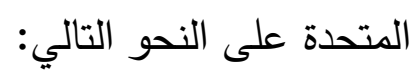

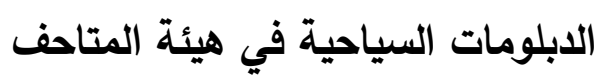
إن المتاحف في إمارة الثارقة لها دور هام ومحوري في تشجيع مهنة الإشاد السياحي، وتعتبر

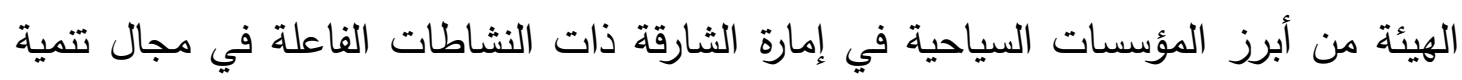
مهنة الإرشاد السياحي في إمارة الثارقة، وذلك من خلال تقديم التدريب الفعال في مجال الإرشاد

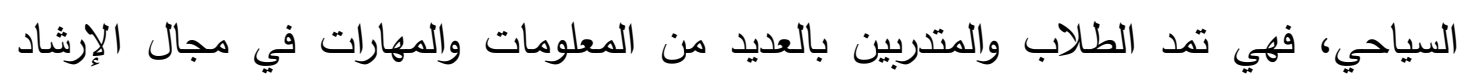
السياحي.

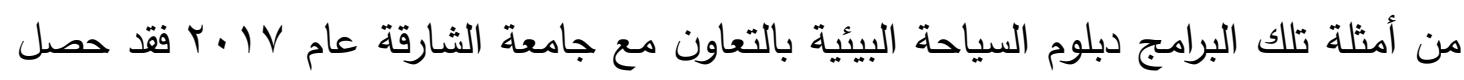

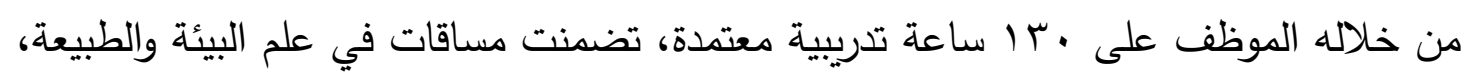

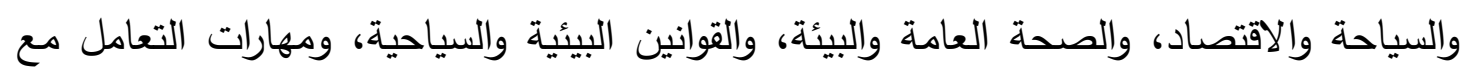

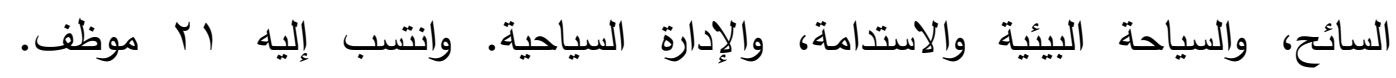
.(www.sharjah.ac.ae) دور هيئة الإنماء السياحي والتجاري دشنت هيئة الإنماء التجاري والسياحي في الثارقة برنامج تدريب وترخيص المشدين السياحيين بالتعاون مع جامعة الثارقة وذلك ضمن استراتيجية الهيئة لتدعيم قدرات المرشدين السياحيين التئين

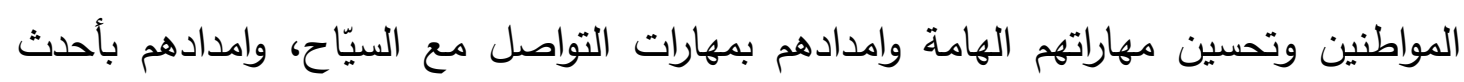

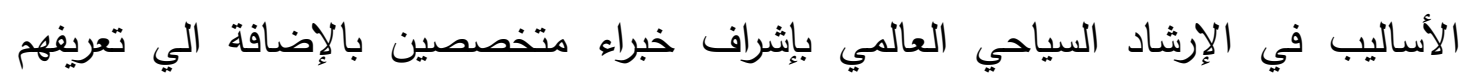

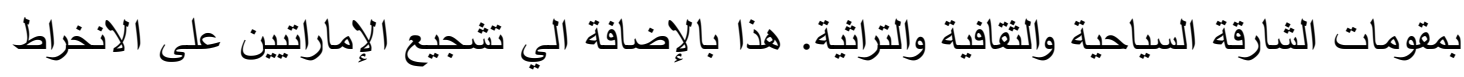

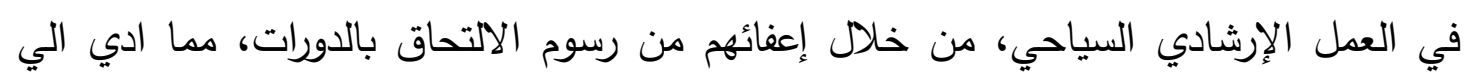

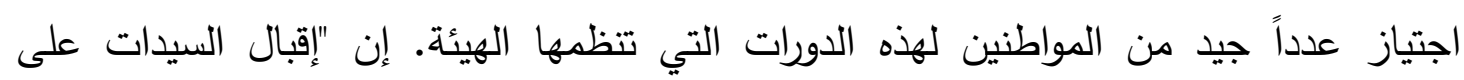

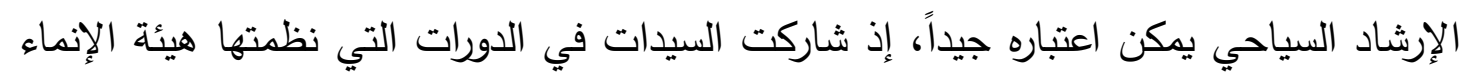

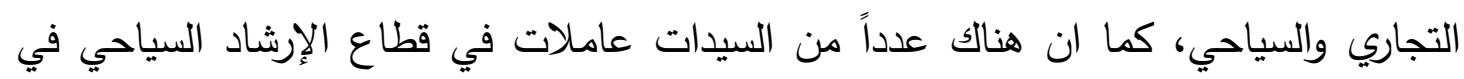


الدولة، وقد فاقت نسبة الخريجات من الإناث في الدورات السابقة نحو بـ ٪ من مجمل المرشدين

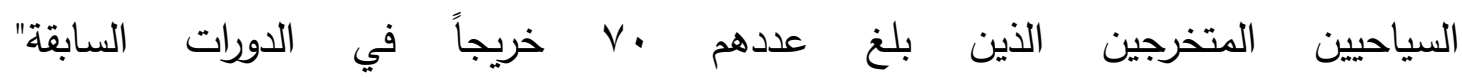
(2012،www.emaratalyoum.com)

إن لهيئة الانماء السياحي والتجاري في إمارة الثارقة دور كبير في تثجيع الإقبال على مهنة

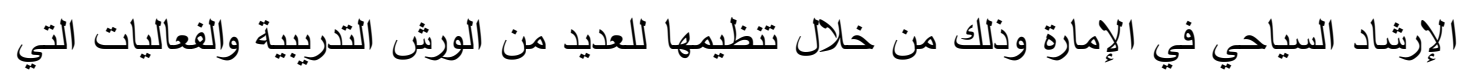

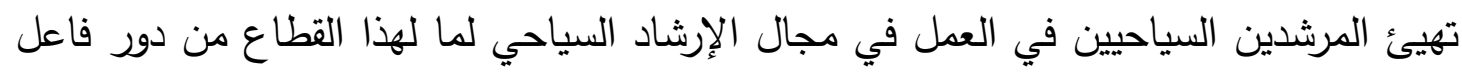

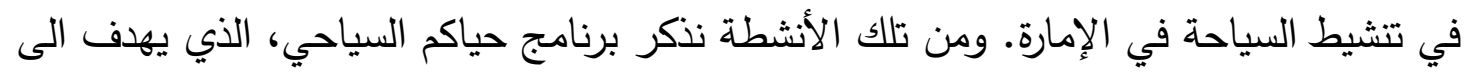

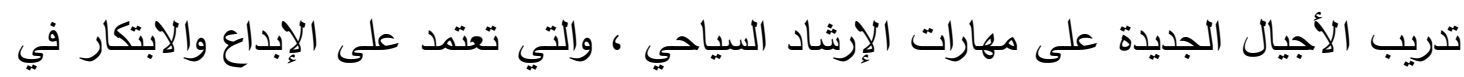

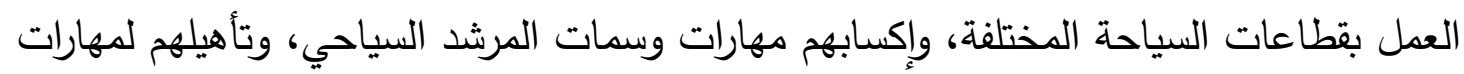
القيادة والإبتكاروالثقافة،والسعادة. واختلفت طرق التدريب بين ورش العمل والجولات الاستكثافية

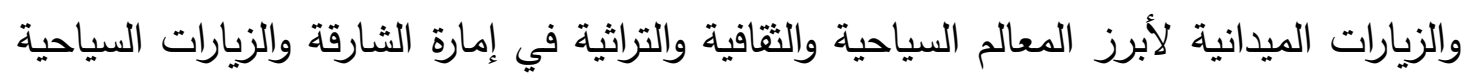
إلى مختلف المتاحف والمعالم السياحية. (www.alkhaleej.ae نتائج دراسة حالة حول برنامج الإرشاد السياحي بجامعة الثارقة (Yww.sharjah.ac.ae ) $(r \cdot r)$ يشكل التراث والتاريخ أساسا قويا في تشييد بنيان الهوية الوطنية وترسيخها في نفوس أبناء أي

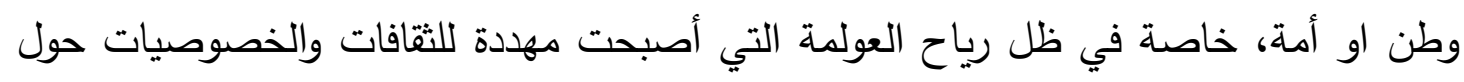

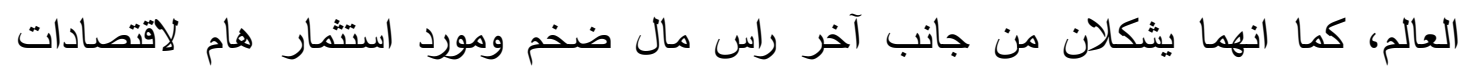

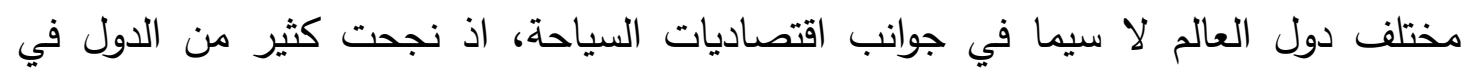

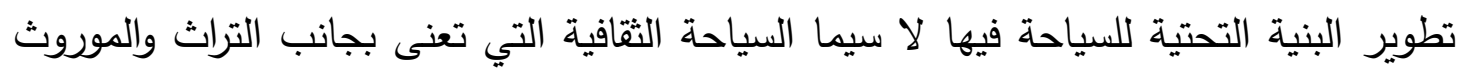

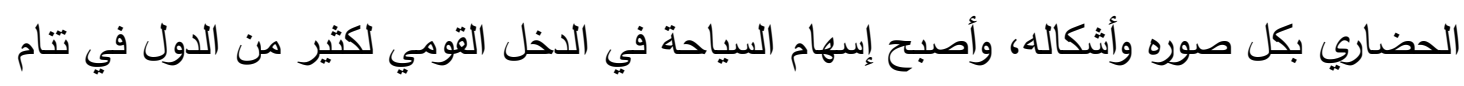

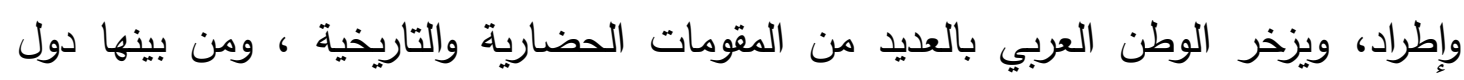

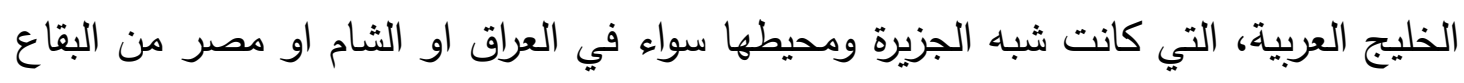
التي شهدت قيام أقدم الحضارات التي عرفها العالم.

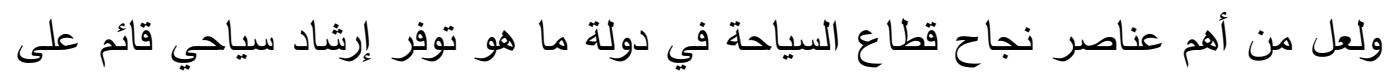

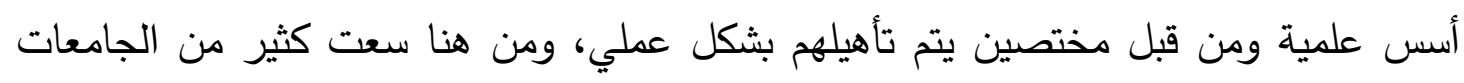

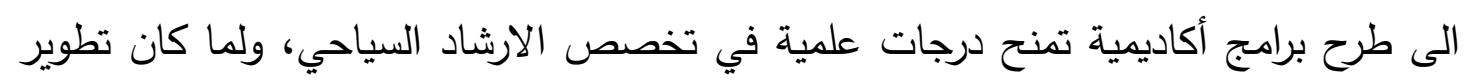

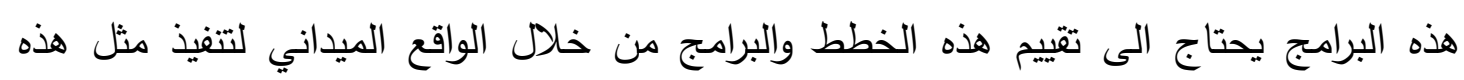

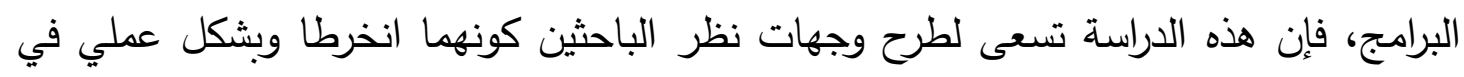


تتفيذ هذه الخطة من خلال التدريس ببرنامج الارشاد السياحي بجامعة الشارقة، ومن خلال تأكيد الجامعة على مراجعة الخطط الدراسية لمختلف البرامج جاء اهتمام الباحثان بتقييم هذه الخطة.

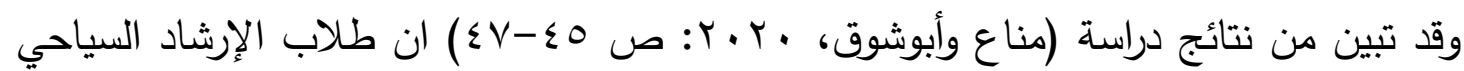
قد يقومون باختيار البرنامج ليس لرغبتهم في الإلتحاق بالتخصص نظس نظرا لميولهم ورغبتهم في

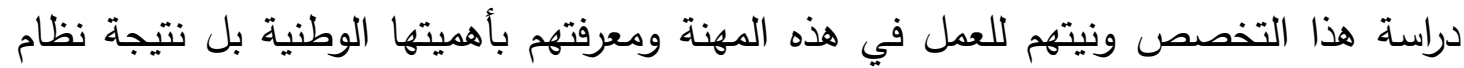
القبول بالجامعات الذي يفرض بعض التخصصات طبقا للمجموع الذي حصلوا عليه في اختبارات الثانوية العامة. هذا بالرغم من أن مناع وأبوشوق قد توصلا الي أن الإقبال قد زاد

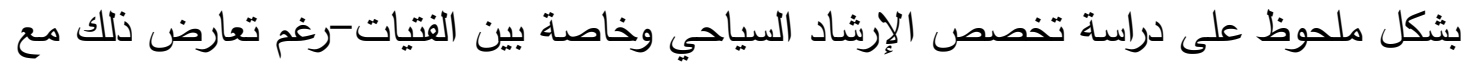

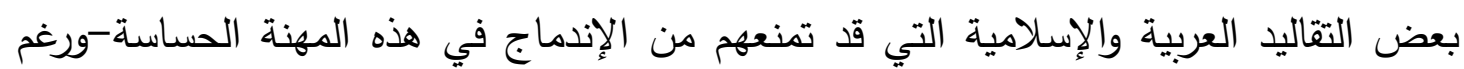

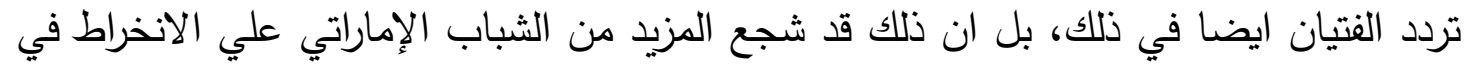

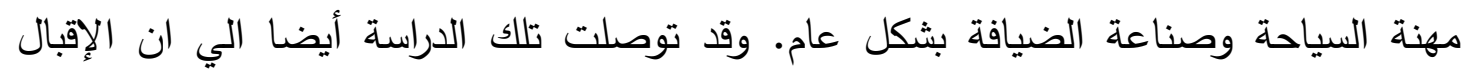

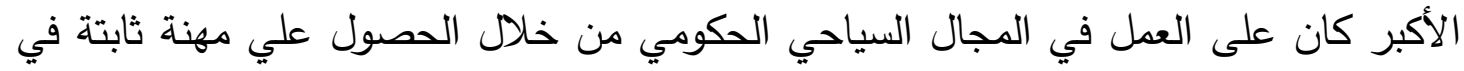

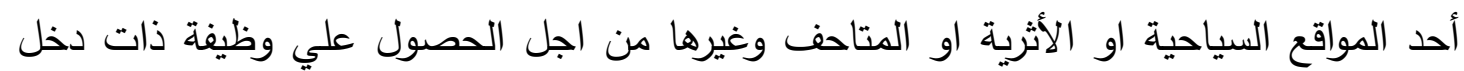
ثابت ومواعيد محددة مما يناسب ظروف المرأة العربية المسؤولة بشكل مباشر عن الأربه الأسرة ورعاية

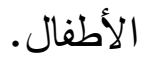
لذلك تواجه الجامعات التي تطرح برامج الارشاد السياحي تحدي الموازنة بين المكون المعرفي في

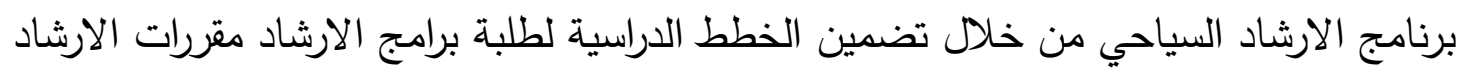

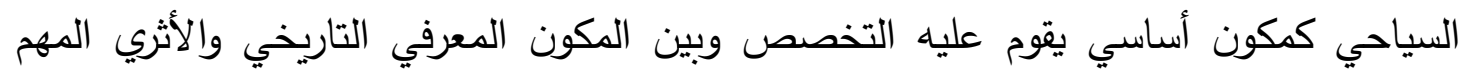
كذلك، والذي يتطلب توفير المقررات العلمية والعملية في تخصص التاريخ التي تتناسب مع المسار المهني وبيئة العمل للطالب الذي سوف يتخرج للعمل كمرشد سياحي في البلد الذي لإلي ينتمي اليه او يقيم فيه او في أي مكان آخر في العالم، وحيث ان مواد التاريخ بعد استثناء

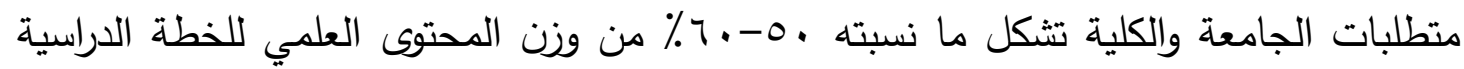
لطالب الارشاد السياحي في العديد من هذه الجامعات الا انه يغلب على بعض من هذه

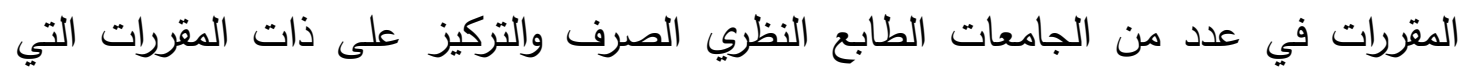
يدرسها الطالب المتخصص في برنامج التاريخ، ولذلك سيحاول البحث دراسة خطة برنامج

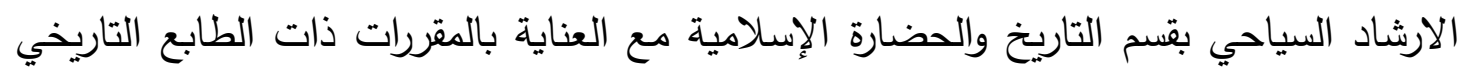

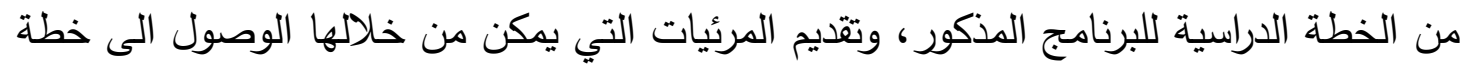

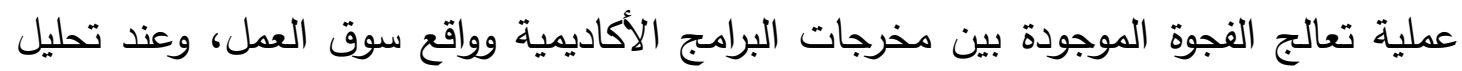
الخطة خطة البرنامج نجدها تتألف من مقررات في التاريخ والسياحة، لذا فقد تم التركيز في 
الدراسة على مقررات التاريخ التي تتنوع بين مساقات منهج دراسة التاريخ والتاريخ القديم والآثار والتاريخ والحضارة الإسلامية والتاريخ الحديث والمعاصر . مقرات التاريخ القديم والآثار:

فاذا ما استثينا مادة منهج دراسة التاريخ التي تلقي في جانب منها الضوء وبشكل جزئي على علم الآثار كفرع من فروع علم التاريخ فإن الخطة لا تتضمن مواد في التاريخ القديم والآثار

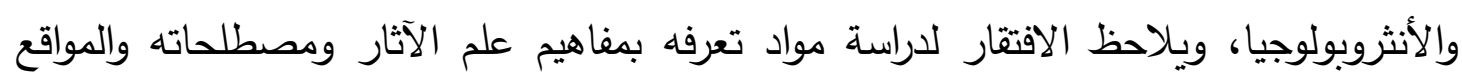
الأثرية المكتشفة التي تعود لحقب ما يعرف بالتاريخ القديم، وهي تعتبر جزء مهم في الخريطة

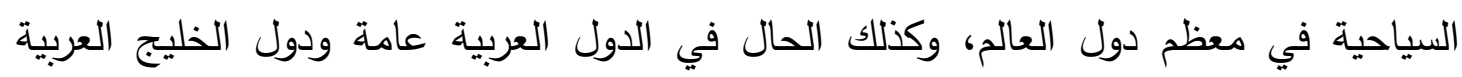
خاصة بما فيها دولة الامارات العربية المتحدة، اذ تعد المتاحف التاريخية والمواقع التاريخية

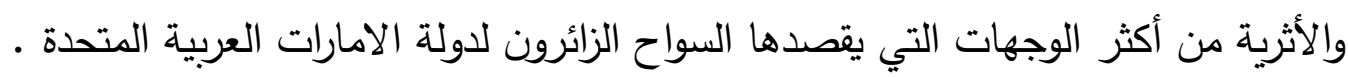

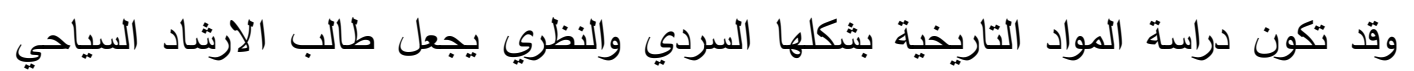
يشعر بأنه يدرس مواد نظرية لا تتصل بشكل مباشر بمعظم الوجهات السياحية والمواقع الأثرية

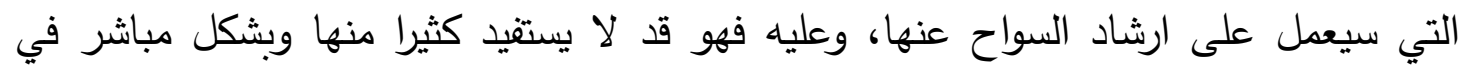

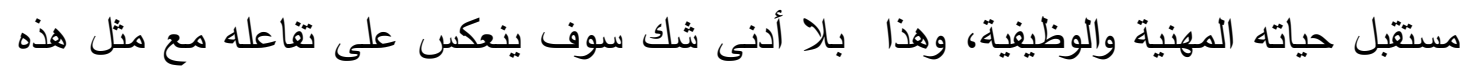

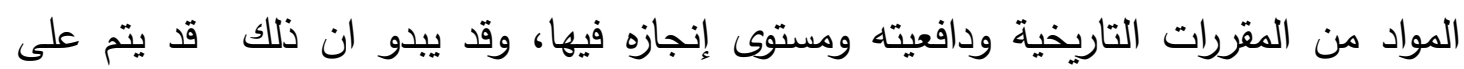

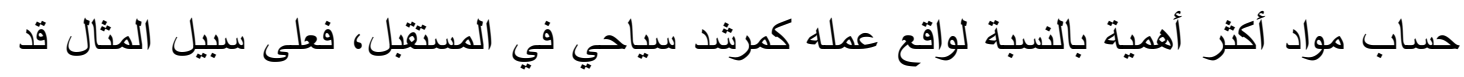

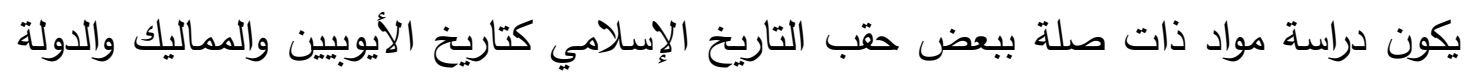

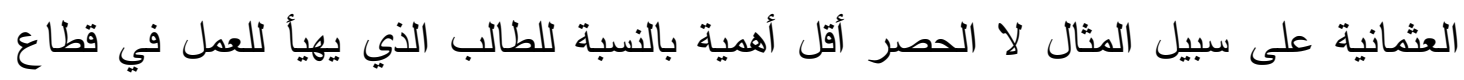

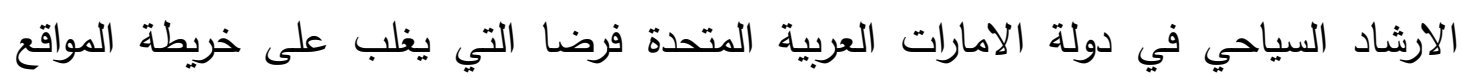

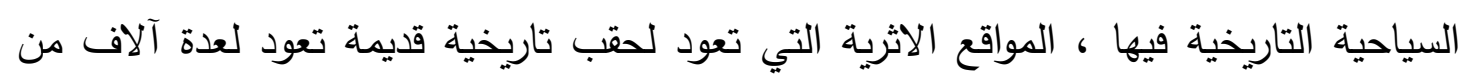
السنوات قبل الميلاد. ومن هنا تكون دراسة مقررات تعرف الطالب بالحضارات والدول التي قامت في الجوار الجغرافي لاسيما في بلاد الرافدين ومصر وبلاد فارس والهند وعمان لإعطاء الطالب فكرة عن تاريخ تلك فئك

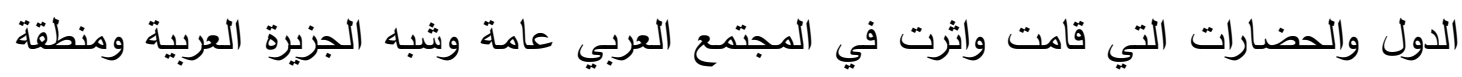

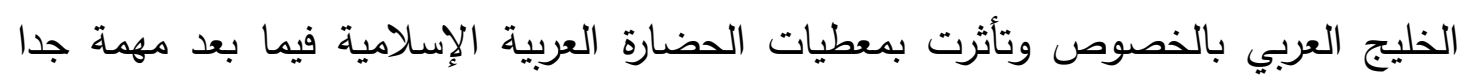
لخريجي برنامج الارشاد السياحي. وواقع الحال ان دراسة الخطة الدراسية لقسم الارشاد السياحي توقف القارئ على ان الطالب لا لادئ التادئ

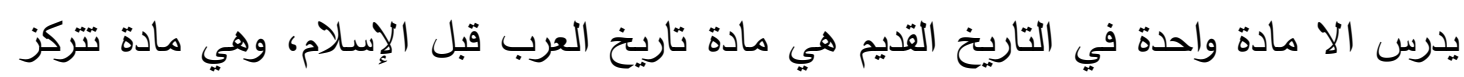

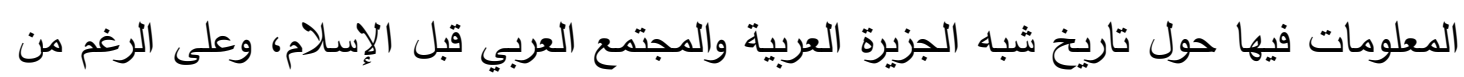


أهمية مواضيع المقرر التي تعتبر مدخلا لـعرفة التغيرات التي طرأت في المجتمع العربي بعد

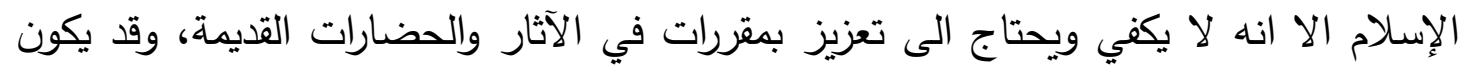

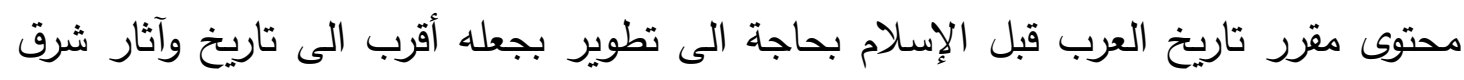

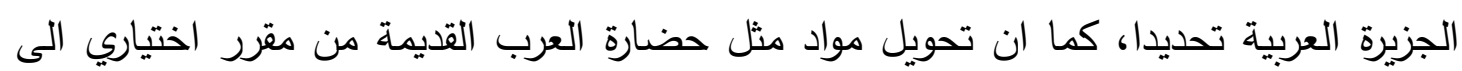

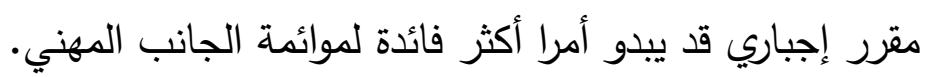

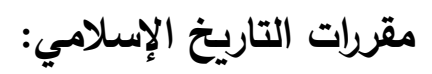
على الرغم من أهية دراسة طالب الارشاد السياحي لمقررات التاريخ الإسلامي التي تؤسس

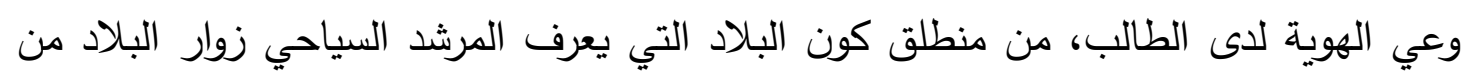

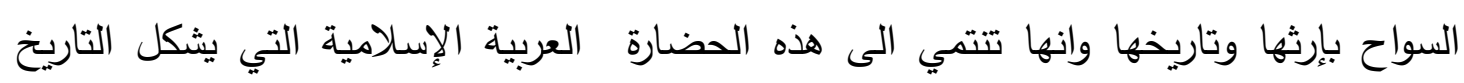

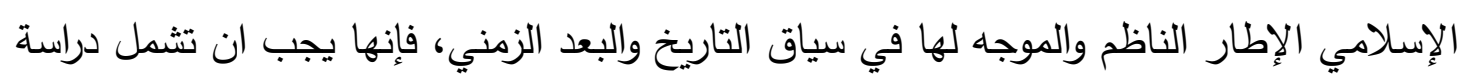

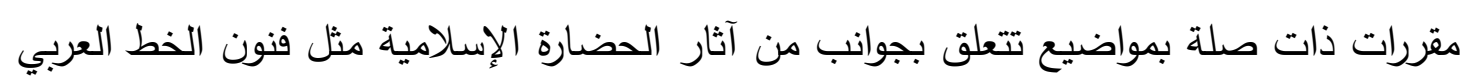

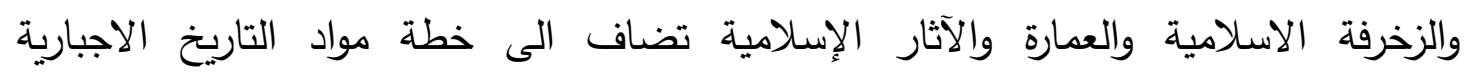

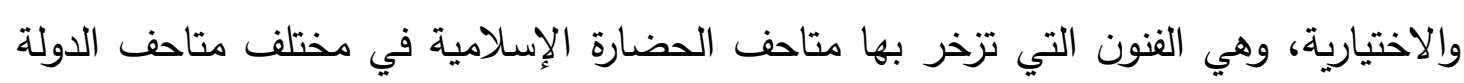

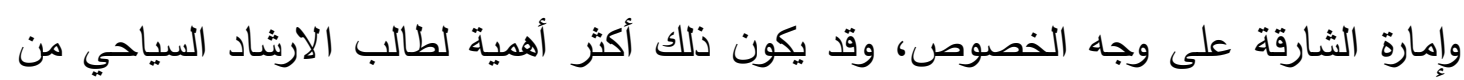

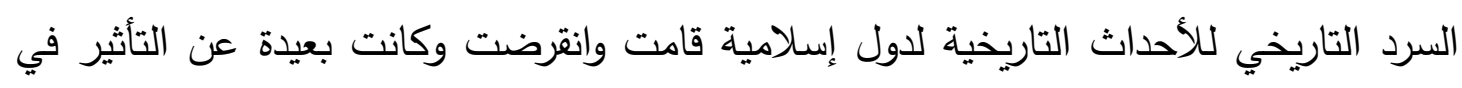
أحداث تخص تاريخ المنطقة في الخليج وشبه الجزيرة العربية. هذه الموائمة والإضافة يمكن ان تشكل اختيارا موفقا يعزز المعرفة التاريخية النظرية التي تركز على الأحداث التاريخية في مختلف حقب التاريخ الإسلامي في المقررات الاجبارية والاختيارية والتي يجب ان تضمن بشكل مفصل في مقررات الحضارة الإسلامية سواء أكانت متطلب كلية

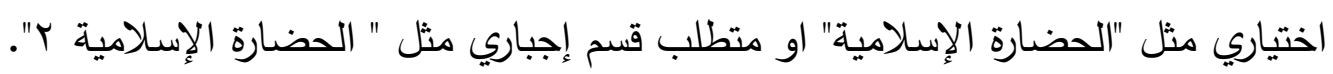

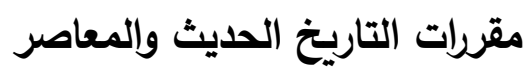

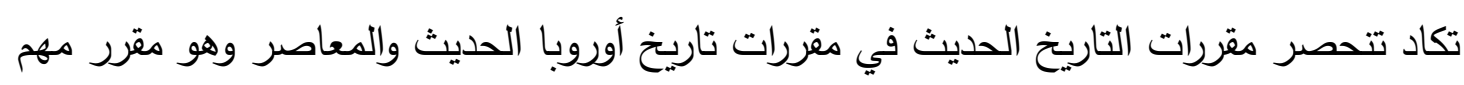

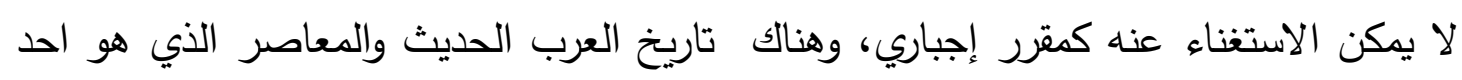

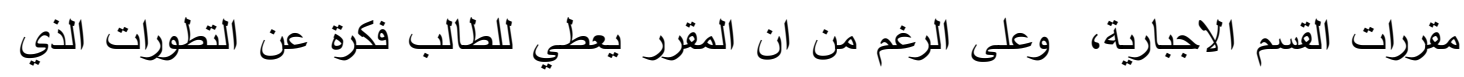

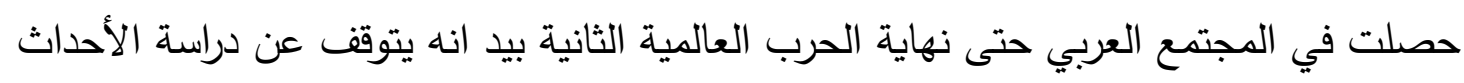

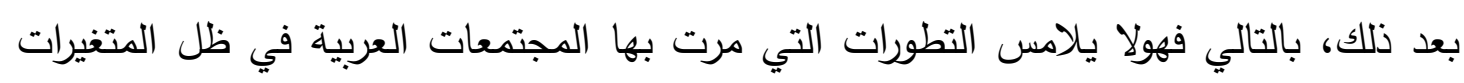

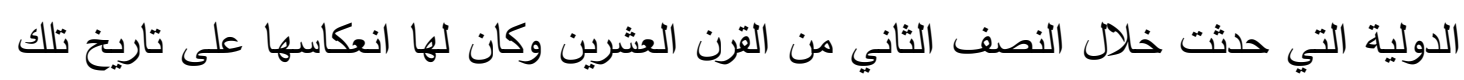

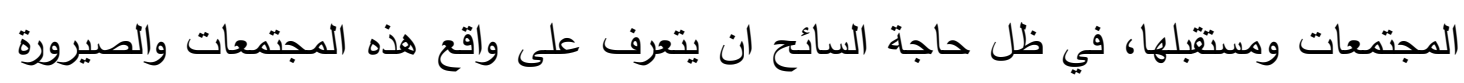

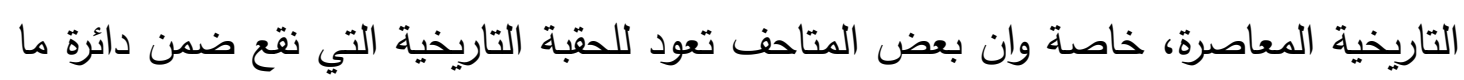


يعرف منهجيا بالتاريخ المعاصر مثل متحف الاتحاد، وهناك مقرر اختياري ضمن مقررات القسم في تاريخ الأميركتين وهو كذلك مهم بيد انه لا يطرح دائما ، فضلا عن ان الطالب يحتاج ان يطلع على الحضارات المعاصرة خاصة المجتمعات ذات الأهمية السياحية على المستوى العالمي في مختلف أصقاع المعمورة، سواء في الشرق او في الغرب ولذلك لا بد من تضمين الخطة مقررات يدرس الطالب فيها جوانب ذات صلة بتاريخ العالم الحديث والمعاصر .

نتائج الاراسة

1. إن الآثار التاريخية اهم عناصر اكتشاف ماضي الشعوب والحضارات؛

r • يعد تراث الأمة من أهم مقومات التقدم السياحي وموردا اقتصاديا هاما للدول السياحية؛ r. تعد الثارقة المقصد الأول للسياحة الترفيهية والعائلية في المنطقة لما تقدمه من أنشطة

$$
\text { وفعاليات سياحية وترفيهية على مدار العام؛ }
$$

ع. تهتم إمارة الثارقة بتظيم العديد من الأنشطة والفعاليات التي تساهم في تتمية مهنة

$$
\text { الإرشاد السياحي؛ }
$$

ه. ترتبط مهنة الإرشاد السياحي بالمواقع التراثية والتاريخية التي تشجع على الإقبال على هذه المهنة وخاصة بين المواطنين الإماراتيين؛ 7. تتمتع السياحة بأهمية قصوى بين القطاعات الأخرى في الهيكل الاقتصادي للدولة؛ V. المرشد السياحي الإماراتي سفير وواجهة متميزة لبلده؛

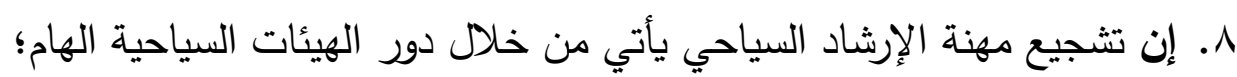
9 ـ تساعد هيئة الإنماء التجاري والسياحي في الثارقة في تشجيع الإماراتيين على الانضمام لمهنة المرشد السياحي؛ • ا.تقوم دائرة الإعلام والثقافة بتشجيع الارشاد السياحي من خلال اعداد برامج التدريب وتوفير فرص العمل للشباب في مجال الإرشاد السياحي؛ ا إ إن وجود تشرع قانوني ينظم مهنة الإرشاد السياحي من عوامل تشجيع تلك المهنة في دولة الإمارات العربية المتحدة؛ r ا. تتيح المراكز الثقافية فرص كثيرة ومتنوعة لممارسة مهنة الإرشاد السياحي؛ سا ـتقوم المتاحف بتعزيز مهنة الإرشاد السياحي في دولة الإمارات العربية المتحدة؛ ع ا.تقدم هيئة المتاحف في إمارة الثارقة التدريب الفعال في مجال الإششاد السياحي من خلال توفير المعلومات والمهارات للطلاب والمتدربين في مجال الإرشاد السياحي؛ ه ا.سعت كثير من الجامعات الى طرح برامج أكاديمية تمنح درجات علمية في تخصص

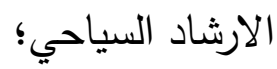




\section{توصيات الدراسة}

ا. اهتمام الهيئات السياحية بالآثار التاريخية كمصدر للتمسك بالهوية الوطنية ومعرفة ماضي الشعوب والحضارات ولدوره في التشيع على الإقبال على مهنة الإرشاد السياحي؛

ץ. زيادة اهتمام الدوائر السياحية بالتراث كمكون أساسي للتقدم السياحي وداعم رئيس لمهنة الإرشاد السياحي؛ r. اهتمام الهيئات السياحية بتشجيع مهنة الإشاد السياحي بإمارة الشارقة من خلال الأنشطة والفعاليات السياحية والترفيهية؛ ء. تتمية القطاعالسياحي في دولة الإمارات العربية المتحدة عموماً وفي إمارة الشارقة على وجه الخصوص بواسطة هيئة الإنماء التجاري والسياحي؛ هـ نشر الوعي بأهمية وظيفة المرشد السياحي الإماراتي كسفير وواجهة متميزة لوطنه من هن خلال المعاهد والجمعيات المختصة؛ 7. إنشاء كلية وطنية للسياحة لتخريج كوادر متخصصة لتزويد المنشآت والمؤسسات السياحية من فنادق ومطاعم ومكاتب طيران وسفر وغيرها بالكفاءات اللازمة؛ V. تشجيع المزيد من المواطنين على الانضمام الى البرامج الأكاديمية التي تطرحها الجامعات لمنح درجات علمية في تخصص الارشاد السياحي؛ ^. ربط مساقات التاريخ والآثار بمجال الإرشاد السياحي لخدمة سوق العمل بكافة البرامج الجامعية المتخصصة؛ - ماك 9 ـ العمل على تكامل مساقات التاريخ والآثار بكافة البرامج الجامعية المتخصصة بما يخدم الهدف الرئيس من مهنة الإششاد السياحي وهو توصيل المعلومة بسهولة ويسر الي السائح؛ • 1 . تبسيط العلوم التاريخية والأثرية بكافة البرامج الجامعية المتخصصة لتتناسب مع تخصص الإرشاد السياحي؛ 1 ا ـ تشجيع طلاب الإرشاد السياحي على دراسة التاريخ والآثار لأنها أساس عملهم المهني؛ r ا ـ تطوير خطة مساقات تخصص الإششاد السياحي بكافة البرامج الجامعية المتخصصة لتتناسب مع طبيعة المناطق والفترات التاريخية التي يتتاولونها أثناء ارشاد السائحين؛ با. الاهتمام بطرح المساقات التي تساعد المرشد السياحي في التعرف على ثقافات وحضارات وتاريخ الشعوب التي سوف يتعامل معها من خلال مهنته؛ 
ع اـ إضافة مساقات ترتبط وتعكس المزيد من عناصر الحضارة الإسلامية مثل فنون الخط العربي والزخرفة الاسلامية والعمارة والآثار الإسلامية لتثري الحوار بين المرشد السياحي والسائح والذي يمثل حوارا بين الحضارات؛ ه ـ ـ طرح المزيد من المقررات التي تعرف الطالب بالحضارات والدول التي قامت في الجوار الجغرافي والتي تبرز التأثير والتأثر الذي حدث بين هذه الحضارات وحضارة دولة

$$
\text { الإمارات؛ }
$$

1 ا. تطوير دور الهيئات السياحية في تشجيع مهنة الإششاد السياحي؛ V V الترويج لبرنامج تدريب وترخيص المرشدين السياحيين الذي تتظمه هيئة الإنماء التجاري

$$
\text { والسياحي في الثارقة ؛ }
$$

1 ا. تشجيع مزيد من المواطنين الإماراتيين على الانخراط في العمل الإششادي السياحي وتغيير الصورة الذهنية السلبية عن صناعة الخدمات بشكل عام؛ 9 ا ـ تفعيل دور دائرة الثقافة والإعلام في إمارة الثارقة في مجال التراث والتشجيع على ودئ الانخراط في الإششاد السياحي كمهمة قومية؛ • ץ. توفير فرص العمل بين الشباب في مجال الإشاد السياحي من خلال خطة للإحلال والتجديد بالهيئات السياحية؛ ا ץ. استبدال غير المتخصصين بغيرهم من خريجي برامج الإرشاد السياحي المؤهلين والمدربين والحاصلين على شهادات علمية في هذا المجال؛ بعيرفين r r. الاهتمام بتطوير تشريع قانوني ينظم الإرشاد السياحي ويشجع على انضمام مزيد من المواطنين الي هذه المهنة:

$$
\text { a }
$$

b تعديل بند المؤهل ليكون حاصل على مؤهل عال في تخصص الإرشاد السياحي او تخصص مناسب مثل الآثار أو التاريخ،

C ت Cعديل بند الجنسية ليكون مواطنا من دولة الإمارات العربية المتحدة، d . السماح لغير الإماراتيين بالحصول على ترخيص ترجمة للغات النادرة مع وجود

$$
\text { مرشد اماراتي مواطن؛ }
$$

r . . الاهتمام بوضع قوانين لحماية الآثار والمحافظة عليها ومنع سرقتها او تداولها او التنقيب عنها خارج نطاق القانون؛ צ ז. العمل على انشاء مزيد من المراكز الثقافية لدورها في تشجيع مهنة الإرشاد السياحي؛ 
هץ. التطبيق العملي لمهنة الإرشاد السياحي داخل المؤسسات الثقافية لخلق فرص متعددة

$$
\text { ومنوعة لمزاولة مهنة الإرشاد السياحي؛ }
$$

جب. الاهتمام بدور المتاحف في تعزيز مهنة الإششاد السياحي في دولة الإمارات العربية المتحدة حيث تتيح المزيد من فرص العمل في هذا المجال؛

ت . . . تجيع المزيد من الأفراد على الانضمام الى الدورات التدربية التي تعقدها هيئة الآثار وهيئة المتاحف في إمارة الشارقة.

الخاتمة

لقد زاد النشاط السياحي في دولة الإمارات العربية المتحدة وتتامي اهتمام السياح والزوار بزيارة المواقع التراثية والتي تعبر عن الثقافة الإماراتية ومن ثم نشأت الرغبة في تتمية مهنة محترفة يمكن فقط لمواطني الدولة العمل بها لقدرتهم علي التعبير عن حضارتهم وتاريخهم وثقافتهم وتراثهم بانتماء وولاء وفخر واعتزاز، وهي مهنة المرشد السياحي. لذا قامت الدراسة ببحث أهمية الإرشاد السياحي في قطاع السياحة وخاصة في إمارة الثارقة، بالإضافة الي دور الإرث التاريخي في تعزيز تلك المهنة ودور الهيئات السياحية والثقافية والإعلامية في تشجيعها، ودعم جهود التعليم والتدريب والتأهيل لهذه المهنة، وكذلك أهمية تواجد اطار قانوني يخدم تلك المهنة. لقد توصلت الدراسة لعدد من النتائج من خلال الدراسة النظرية وكذلك تحليل الدراسة الميدانية حول برنامج الإرشاد السياحي بجامعة الشارقة وابرزت أهمية تناول التاريخ والآثار بشكل يتناسب وحساسية الإرشاد السياحي الذي يتعامل عادة مع السياحة كصناعة حساسة تقدم الثقافة من

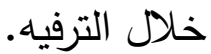

\section{قائمة المراجع أولاً: المراجع الأجنبية}

1. Cruz, Zenaida L.2008, Principles and Ethics of Tour Guide, Published by Rex Book Store, Manilla (Philippines), pp. 2.

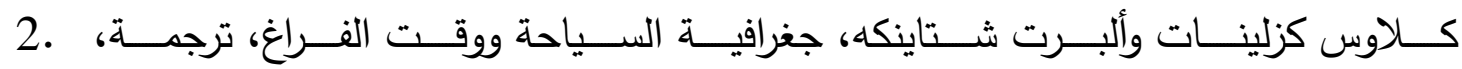

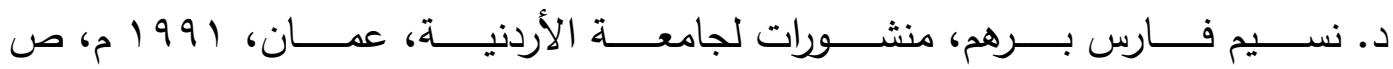
$.11 \varepsilon$

3. Maryam Taha Mannaa \& Mohamed Abou-Shouk, Students' Perceptions towards Working in the Tourism and Hospitality Industry in United Arab Emirates, Al-Adab Journal, Volume 1, No. 135 
المجلة الدولية للتراث والسياحة والضيافة IJHTH تصدر ها كلية السياحة والفنادق - جامعة الفيوم

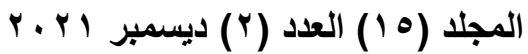

(December) 2020, University of Baghdad, Baghdad, Iraq: pp 45-47.

DOI: https://doi.org/10.31973/aj.v1i135.842 


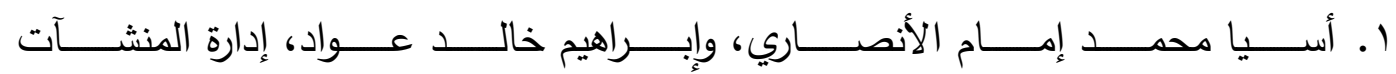

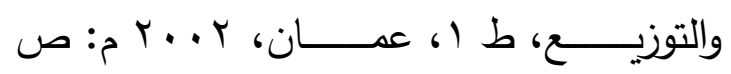
فاء للنشـ

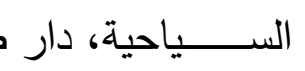

r. أشرف محمد صالح؛ التراث الحضاري في الوطن العربي، أسباب الدمار والتلف وطرق الحفاظ، بحث منشور بندوة الحفاظ على التراث الحضاري في الوطن العربي بين النظرية

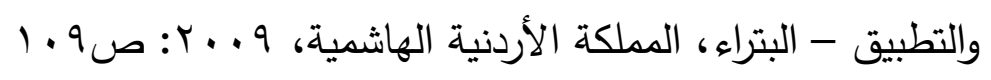

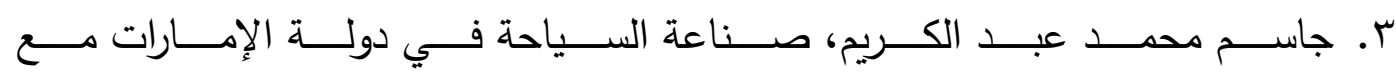

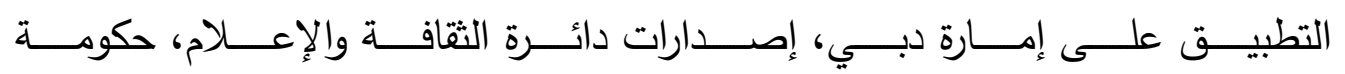

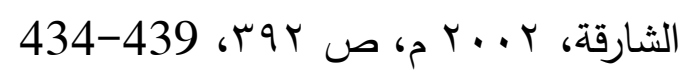

ـ. جعفر زهير فضل الله: واقع المعالم التراثية اللبنانية وكيفية الحفاظ عليها، بحث منشور بندوة الحفاظ على التراث الحضاري في الوطن العربي بين النظرية والتطبيق - البتراء،

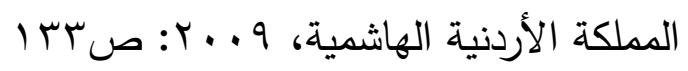

0. حاج قويدر عبد الرحيم وشنيني حسين، مداخلة بعنوان “السياحة الثقافية وأهميتها في

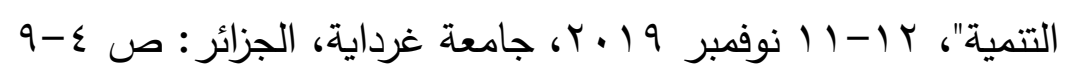

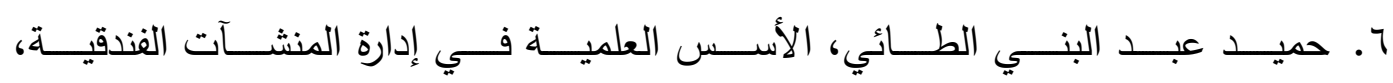

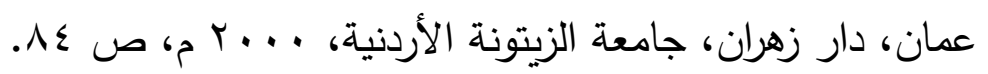

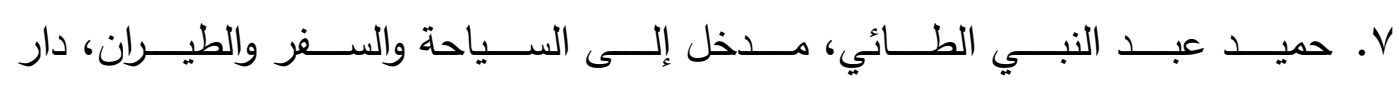

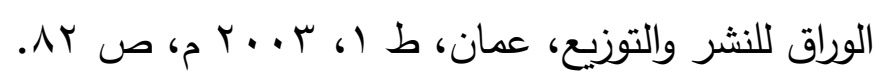

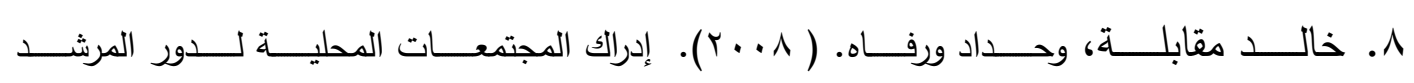

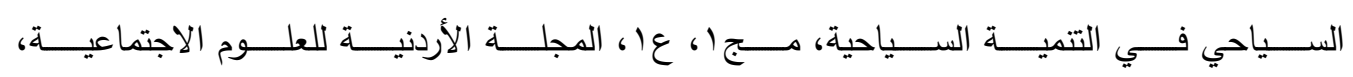

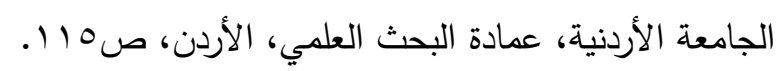

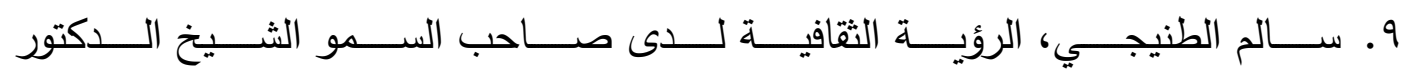

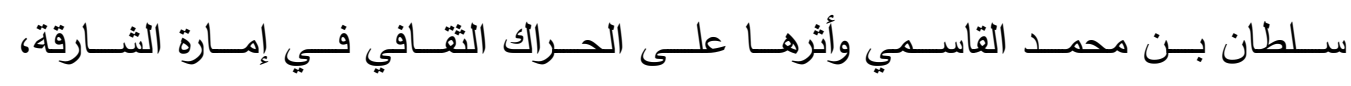

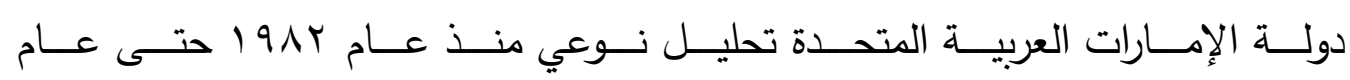

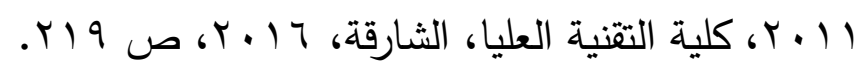

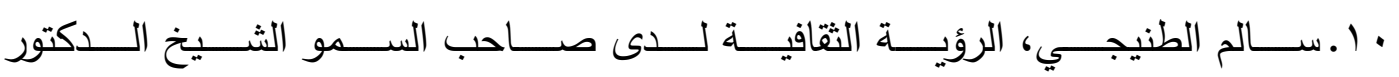

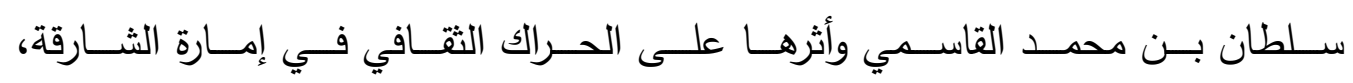

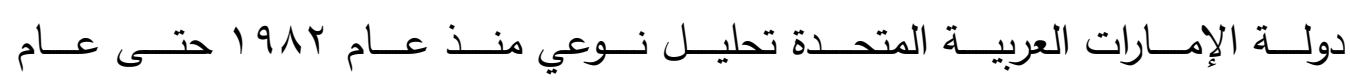




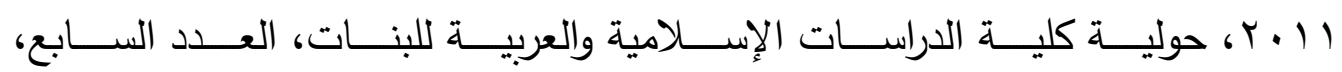

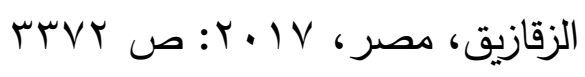

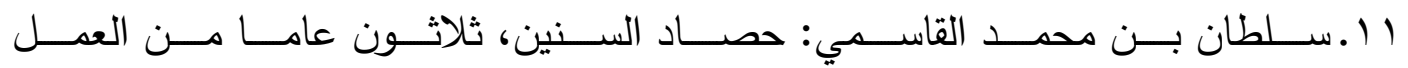
الثقــافي فــي الثـــارقة، منشــورات القاســــي، الثـــارقة، دولـــة الإمـــارات العربيـــة

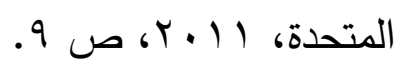

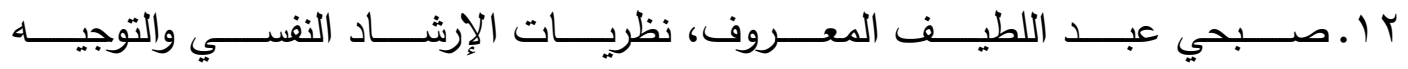

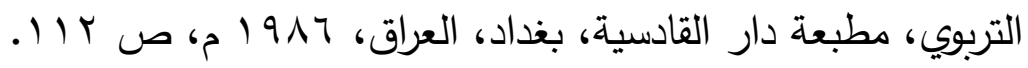

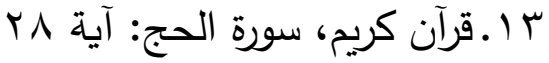

$$
\begin{aligned}
& \text { ع ا.قرآن كريم، سورة الروم: آية بـ } \\
& \text { 1 ـقرآن كريم، سورة العنكبوت: آية } 19
\end{aligned}
$$

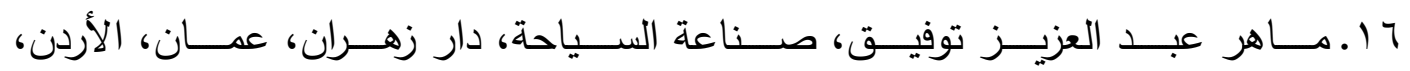

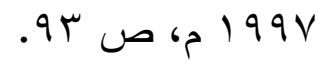

V ا ـ مثنــى طـــه الحــوري وإســماعيل علـي الــدباغ، اقتصـــاديات الســفر الســياحية،

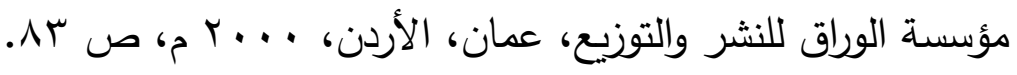

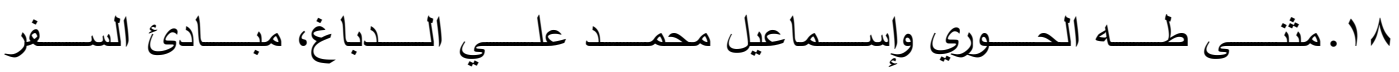

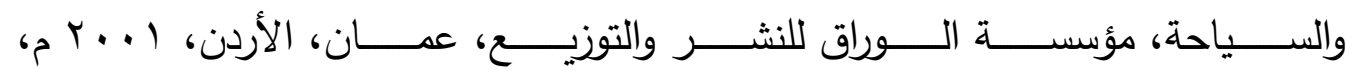
ص ص VT.

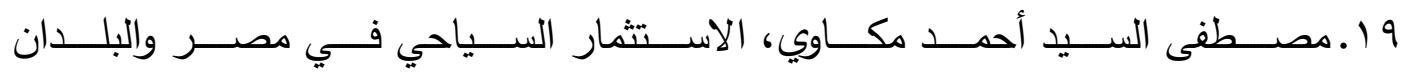

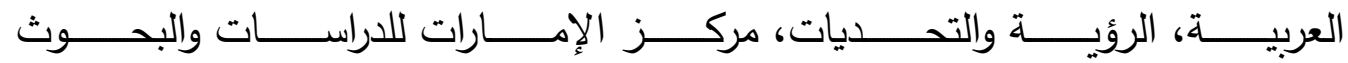

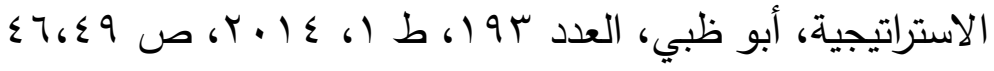

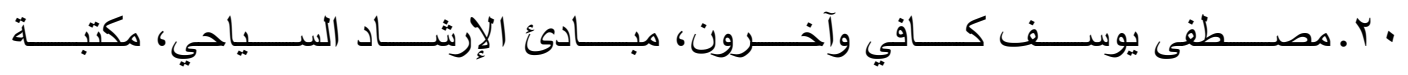

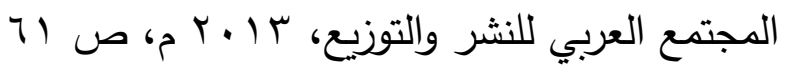
ثالثا: الندوات والمحاضرات:

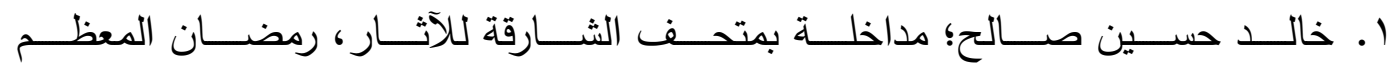

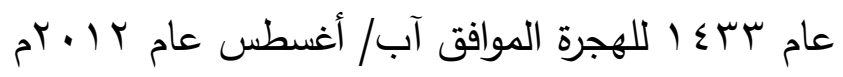

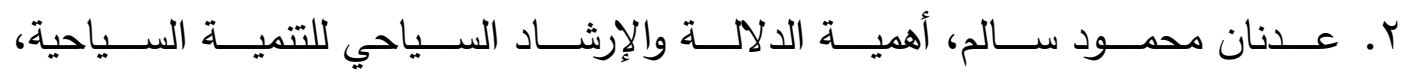

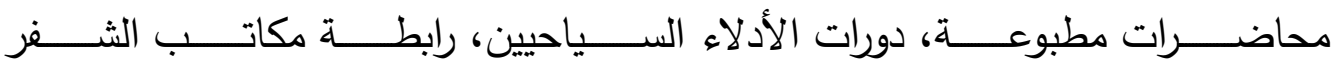
والسياحة في العراق، المركز العام بعداد، آذار سو9 1 م، ص ؟9 9. 
المجلة الدولية للتر اث والسياحة والضيافة IJHTH تصدر ها كلية السياحة والفنادق - جامعة الفيوم

ك. الفيتـــوري عمــر مـــادي وعـــادل حســين المبــروك: الحفـــاظـ علــى التـــراث

التــاريخي المعدــاري والعدرانــي، بحــث منشـــور بنــدوة الحفـــاظ علــى التــراث

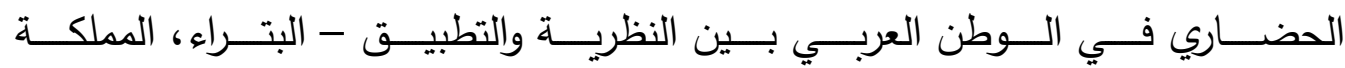

$$
\text { الأردنية الهاشمية، } 9 \text {. . ץ: صع }
$$

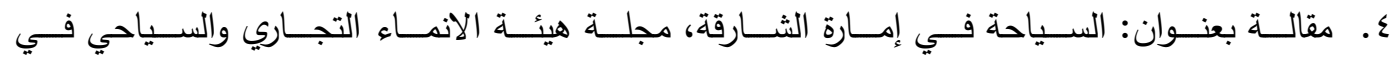

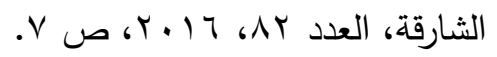

رابعا: القرارات:

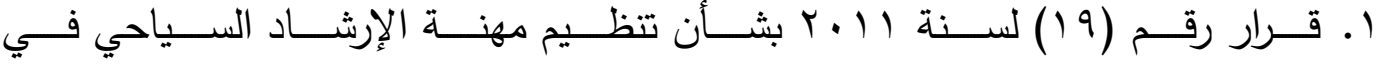

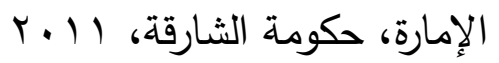

خامسا: مراجع الإلكترونية:

1. https://www.alkhaleej.ae/2018-08-

17/\%D8\%AA\%D8\%AF\%D8\%B1\%D9\%8A\%D8\%A8- accessed at:

$15 / 2 / 2021$.

2. https://www.emaratalyoum.com/life/four-sides/2012-07-03-1.496237

Accessed at: 12/1/2021.

3. https://www.sharjah.ac.ae/ar/Media/Pages/news-details.aspx?mcid=2151

Accessed at: 30/6/2021.

4. https://www.sharjah.ac.ae/en/academics/Colleges/ahss/dept/hic/Pages/Bach elor-of-Arts-In-History-And-Islamic-Civilization-Tourism-Guidance.aspx accessed at:25/6/2021.

The Historical Heritage and the Tour Guide ... Challenges and Integration:

The Tourism Guidance Program at the University of Sharjah as a model.

Dr. EmadEddin Ahmed AbuEIEnain

Assistant Professor, College of Arts and Humanities, University of

Sharjah

eabuelenain@sharjah.ac.ae

Dr. Ali Hassan Khamis

Assistant Professor, College of Arts and Humanities, University of

Sharjah

ali.khamis@sharjah.ac.ae 


\begin{abstract}
It is important to highlight the close relationship between history and tourist guides, as there is a link that still exists between them since the inception of the profession of tourist guides in its modern concept. Based on this relationship, the study of history in depth is one of the basics of the study of tourism guidance. Therefore, all training and educational programs have emphasized on history being a major component in the curricula of tourism guidance in various universities and institutes. In fact, history has become a decisive criterion in evaluating the tour guide, whether to obtain a license to practice the profession or to renew that license whenever necessary and in accordance with the valid regulations in each country.
\end{abstract}

Accordingly, the study deals with discussing this issue from a new and advanced perspective to keep pace with the changes that have arisen in this ancient profession and how the field of history contributes to its development and with the changes of the modern era in this sector. The study deals with the challenges facing the tour guide in light of the diversity and variety of tourism patterns, and even with the change in the nature of tourists' diverse needs and desires. Therefore, the study assumes the need for the history courses to adapt with these changes and this diversity, which is a feature of our modern age. This will happen through the integration of the historical, tourism and tourism guidance courses through a realistic study of the requirements of the tourism market and through a perspective that focuses on what the tour guide actually needs in his work. The study discusses how to modify the history curricula for the purpose of tourism guidance and to encourage the students of tourism guidance to study what benefits them in their field of work through a new concept invented by the study, which is the (Historical Tourism Structure).

The study highlights, in this regard, the importance of heritage courses, which are concerned with studying heritage in all its forms and types. It contributes to achieving the historical impact in its tourism concept, both on the tour guide and then on the tourists themselves. The study aims to reach the means and methods that attract both the tour guide and the tourist to enjoy history. The study confirms that this methodology in the study of history will not undermine the historical legacy, but it will give history elegance and mental image that will last in the mind of the tourist for a long time This is the criterion for the success of the tour guide, which will make the tourist an important element in promoting our ancient culture. The study will benefit from the practice of integrating history and tourism in the tourism experience and the field of tourism guidance in the United Arab Emirates - the Emirate of Sharjah, as a spatial and objective framework.

Key words: Tourism Types - Tour Guidance - History - Heritage Learning - Culture 